Maria DePtuŁa

ORCID 0000-0003-3888-7623

Uniwersytet Kazimierza Wielkiego

w Bydgoszczy

ANNA BORUCKA

ORCID 0000-0003-4872-5986

Krajowe Biuro ds. Przeciwdziałania Narkomanii

$w$ Warszawie

\title{
PROBLEMY I POTRZEBY UCZNIÓW KLAS IV SZKOEY PODSTAWOWEJ W RELACJACH Z RÓWIEŚNIKAMI ${ }^{1}$
}

Abstract. Deptuła Maria, Borucka Anna, Problemy i potrzeby uczniów klas IV szkoły podstawowej w relacjach z rówieśnikami [Problems and Needs of 4th Grade Students in their Relations with Peers]. Studia Edukacyjne nr 56, 2020, Poznań 2020, pp. 57-84. Adam Mickiewicz University Press. ISSN 1233-6688. DOI: $10.14746 /$ se.2020.56.4

The aim of the paper is to present the results of longitudinal questionnaire surveys carried out among students of the 4th grade on their problems and needs in relations with peers.

Method: Students from 17 classes from all IV grades existing in the 2017/2018 school year in public schools in Bydgoszcz took part in the study. An anonymous questionnaire containing 21 closed-end questions and open questions regarding the relationship with peers and teachers was used.

${ }^{1}$ Badanie przeprowadzono w ramach projektu: „Niebieskoocy” w naszej szkole - przezwyciężanie stereotypów drogą do tworzenia uczniom lepszych warunków rozwoju, dofinansowanego ze środków przyznanych autorom projektu - Marii Deptule i Szymonowi Borsichowi w trybie konkursowym przez Państwową Agencję Rozwiązywania Problemów Alkoholowych, w ramach Narodowego Programu Zdrowia na lata 2016-2020 - umowa z UKW Nr 6/53/3.4.3/17/DEA. Program badań pozytywnie zaopiniowała Komisja ds. Etyki Badań Naukowych w Instytucie Pedagogiki na Wydziale Pedagogiki i Psychologii Uniwersytetu Kazimierza Wielkiego w Bydgoszczy. Autorzy uzyskali pisemną zgodę rodziców na udział dzieci w badaniach. Opis projektu i części wykonanych prac znajduje się w publikacjach: M. Deptuła, Sz. Borsich, "Niebieskoocy” w naszej szkole - przezwyciężanie stereotypów droga do tworzenia uczniom lepszych warunków rozwoju w klasie szkolnej, Studia Edukacyjne, 2017, 46, s. 153-168; Sz. Borsich, M. Deptuła, Propozycja narzędzia do pomiaru natężenia poczucia zagrożenia stereotypem wśród dzieci, opracowanego na podstawie koncepcji multizagrożeń Jenessy Shapiro i Stevena Neuberga, Studia Edukacyjne, 2018, 49, s. 185-213. 
Results: The qualitative analysis was used to distinguish categories of students' statements, which referred to individual experiences related to (1) functioning among peers and (2) the social climate of the school.

Quantitative analyses did not show any correlation between student statements and variables related to the school environment. In contrast, there was a correlation between the frequency of statements about changes in the class and the wishes related to the desirable behavior towards the respondent and the quality of the conditions of psychosocial development in relation with peers.

Key words: problem and needs of students, peer's relations, class climate

\section{Wstęp}

Celem niniejszego artykułu jest przybliżenie problemów i potrzeb zgłaszanych przez uczniów klas IV szkoły podstawowej, które wynikają z ich codziennych doświadczeń $\mathrm{w}$ relacjach $\mathrm{z}$ rówieśnikami w klasie szkolnej oraz zachodzących w tym zakresie zmian w trakcie roku szkolnego. Wyniki badań wskazują, że pozytywny klimat szkoły, na który składają się cechy relacji społecznych w szkole, cechy środowiska kształcenia i wychowania oraz poczucie bezpieczeństwa fizycznego i emocjonalnego dzieci, ogranicza występowanie zachowań ryzykownych wśród uczniów ${ }^{2}$. Relacje z kolegami i koleżankami, które zaspokajają ważne potrzeby psychiczne, jak potrzeba uznania, akceptacji, przynależności i bezpieczeństwa, odgrywają istotną rolę w kształtowaniu poczucia własnej wartości oraz sprzyjają otrzymaniu wsparcia ze strony rówieśników $\mathrm{w}$ trudnych sytuacjach ${ }^{3}$. Spostrzeganie relacji z nauczycielami i rówieśnikami jako pozytywne ma szczególne znaczenie $\mathrm{w}$ przypadku dzieci zagrożonych wystąpieniem zaburzeń zachowania. Może im to pomóc w pokonaniu przeciwności losu, sprzyjać rozwojowi i odnoszeniu sukcesów w nauce ${ }^{4}$.

$\mathrm{W}$ artykule przedstawiono wybrane wyniki podłużnych badań ankietowych uczniów klas IV, dotyczące jakości relacji z rówieśnikami. Pochodzą

${ }^{2}$ M. Kulesza, Klimat szkoty a zachowania przemocowe uczniów w świetle wybranych badań empirycznych. www.seminare.pl/24/Kulesza 2007.pdf [dostęp: 12.11.2018]; K. Ostaszewski, Czynniki ryzyka i czynniki chroniace w zachowaniach ryzykownych dzieci i młodzieży, [w:] Czynniki chroniace młodzież 15-letnia przed podejmowaniem zachowań ryzykownych, red. J. Mazur, I. Tabak, A. Małkowska-Szkutnik, K. Ostaszewski, H. Kołoło, A. Dzielska, A. Kowalska, Warszawa 2008, s. 19-45.

${ }^{3}$ M. Deptuła, Odrzucenie rówieśnicze. Profilaktyka i Terapia, Warszawa, 2013.

${ }^{4}$ N. Garmezy, Stres-Resistant Children: The Search for Protective Factors, [w:] Recent Research in Developmnetal Psychopatology, red. J. Stevenson, Oxford - New York - Toronto - Sydney - Paris - Frankfurt 1995, s. 213-234; M.A. Zimmerman, R. Arunkumar, Resiliency research: Implications for schools and policy, Social Policy Report. Society for Research in Child Development, 1994, 9(4), s. 1-19; S.S. Luthar, Resilience in development. A synthesis of research across five decades, [w:] Developmenthal Psychopatology: Risk, disorder, and adaptation, Volume 3 (2 edition), red. D. Cicchetti, D.J. Cohen, New York 2006, s. 740-795; M. Deptuła, Odrzucenie rówieśnicze; P.P. Kwiatkowski, Mądrość - zasoby - pozytywna adaptacja, [w]: Teorie i konteksty profilaktyki niedostosowania społecznego, red. P. Kwiatkowski, Wrocław 2016, s. 254-339. 
one z odpowiedzi dzieci na pytanie otwarte zamieszczone na końcu ankiety zawierającej 21 pytań zamkniętych, którą badani anonimowo wypełniali na początku i pod koniec roku szkolnego. Pytanie brzmiało: Jeśli jest coś, co chciałabyś/chciałbyś zmienić w swojej klasie, prosze napisz o tym w tym miejscu ${ }^{5}$. Przeprowadzono analizę jakościową odpowiedzi dzieci, a następnie analizy ilościowe obejmujące zróżnicowanie ich życzeń w zależności od:

- płci i wieku (w badanych zespołach klasowych znajdowali się uczniowie, którzy rozpoczęli naukę w wieku 6 i 7 lat);

- warunków rozwoju psychospołecznego uczniów w relacjach z rówieśnikami, ustalonych na podstawie odpowiedzi badanych na pytania zamknięte tej samej ankiety, w której znajdowało się wspomniane wyżej pytanie otwarte;

- poziomu deklarowanego przez badanych stresu związanego ze szkoła i nauką;

- stosunku emocjonalnego do szkoły.

\section{Charakterystyka badanej próby i procedury badawczej}

Badano uczniów 17 klas wylosowanych ze wszystkich klas IV istniejących w roku szkolnym 2017/2018 w publicznych szkołach ogólnodostępnych w Bydgoszczy. Autorzy i realizatorzy projektu przedstawili go rodzicom na zebraniach organizowanych przez wychowawców klas we wrześniu 2017 roku, prosząc o pisemną zgodę na udział dzieci w badaniu. Podstawowe dane o badanej próbie przedstawiono w tabeli 1.

Tabela 1

Zestawienie liczby uczniów, którzy odpowiedzieli i nie odpowiedzieli

na pytanie otwarte w ankiecie dotyczącej warunków rozwoju psychospołecznego $\mathrm{w}$ relacjach z rówieśnikami

\begin{tabular}{|c|c|c|c|c|c|c|c|c|c|c|c|c|}
\hline & \multicolumn{6}{|c|}{ I pomiar } & \multicolumn{6}{|c|}{ II pomiar } \\
\hline & \multicolumn{2}{|c|}{$\begin{array}{c}\text { udzielili } \\
\text { odpowie- } \\
\text { dzi }\end{array}$} & \multicolumn{2}{|c|}{$\begin{array}{c}\text { nie udzie- } \\
\text { lili odpo- } \\
\text { wiedzi }\end{array}$} & \multicolumn{2}{|c|}{ razem } & \multicolumn{2}{|c|}{$\begin{array}{l}\text { udzielili } \\
\text { odpowie- } \\
\text { dzi }\end{array}$} & \multicolumn{2}{|c|}{$\begin{array}{c}\text { nie udzie- } \\
\text { lili odpo- } \\
\text { wiedzi }\end{array}$} & \multicolumn{2}{|c|}{ razem } \\
\hline & $\mathrm{N}$ & $\%$ & $\mathrm{~N}$ & $\%$ & $\mathrm{~N}$ & $\%$ & $\mathrm{~N}$ & $\%$ & $\mathrm{~N}$ & $\%$ & $\mathrm{~N}$ & $\%$ \\
\hline Dz. & 86 & 57,0 & 65 & 43,0 & 151 & 100 & 87 & 57,6 & 64 & 42,4 & 151 & 100 \\
\hline Ch. & 74 & 48,1 & 80 & 58,9 & 154 & 100 & 79 & 51,3 & 75 & 48,7 & 154 & 100 \\
\hline Razem & 160 & 52,5 & 145 & 47,5 & 305 & 100 & 166 & 54,4 & 139 & 45,6 & 305 & 100 \\
\hline
\end{tabular}

${ }^{5} \mathrm{~W}$ badaniach wykorzystano mobilną pracownię diagnostyczną składającą się z tabletów i rutera, a anonimowość zapewniono dzieciom dzięki posługiwaniu się przez nie we wszystkich pomiarach tym samym 7-cyfrowym kodem, które same wylosowały, a wychowawca przechowywał w zamkniętych kopertach w klasie. 


\begin{tabular}{|l|c|c|c|c|c|c|c|c|c|c|c|c|}
\hline $\begin{array}{l}\text { Rocznik } \\
2005\end{array}$ & 3 & & 1 & & 4 & & 2 & & 2 & & 4 & \\
\hline $\begin{array}{l}\text { Rocznik } \\
2006\end{array}$ & 0 & & 5 & & 5 & & 0 & & 5 & & 5 & \\
\hline $\begin{array}{l}\text { Rocznik } \\
2007\end{array}$ & 101 & 53,7 & 87 & 46,3 & 188 & 100 & 107 & 56,9 & 81 & 43,1 & 188 & 100 \\
\hline $\begin{array}{l}\text { Rocznik } \\
2008\end{array}$ & 51 & 50,5 & 50 & 49,5 & 101 & 100 & 56 & 55,4 & 45 & 44,6 & 101 & 100 \\
\hline Razem & 155 & 52,0 & 143 & 48,0 & $298^{*}$ & 100 & 165 & 55,4 & 133 & 44,6 & $298^{*}$ & 100 \\
\hline
\end{tabular}

* Liczba badanych jest mniejsza od 305, ponieważ dla 7. dzieci brakowało danych odnośnie roku urodzenia.

Na pytanie otwarte w I i II pomiarze udzieliło odpowiedzi prawie tyle samo uczniów. W obu pomiarach odsetek dziewcząt udzielających odpowiedzi był wyższy niż chłopców. Wśród badanych formułujących życzenia co do pożądanych zmian $\mathrm{w}$ klasie i/lub sposobu traktowania ich przez rówieśników odsetek uczniów, którzy rozpoczęli naukę w wieku 7. lat (rocznik 2007) i w wieku 6. lat (rocznik 2008) był zbliżony. W badaniach wzięło także udział 9. uczniów z rocznika 2005 i 2006, jednak w analizach zróżnicowania wypowiedzi badanych ze względu na wiek ich wypowiedzi nie brano pod uwage z uwagi na niewielką liczbę dzieci. Badania przeprowadzone przez Marię Deptułę w roku 2016 na losowej próbie reprezentatywnej dla uczniów klas IV, V i VI publicznych szkół podstawowych w Bydgoszczy w roku szkolnym 2015/2016, liczącej 901 uczniów $^{6}$, odpowiedzi na pytanie otwarte w takiej samej ankiecie udzieliło prawie o $10 \%$ mniej badanych $(43,2)$. Różnica ta stanowi w pewnym stopniu konsekwencję udziału w badaniach także uczniów starszych klas, bowiem odsetek uczniów klas czwartych udzielających odpowiedzi wynosił 48,0\%. Można więc powiedzieć, że prawie połowa uczniów zgłasza konkretne życzenia dotyczące swojej klasy, jeśli ma taką możliwość, ale częściej w pomiarze z roku 2016 robiły to dziewczynki, a różnice w tym zakresie między nimi i chłopcami były statystycznie istotne.

\section{Wyniki}

Poniżej przedstawiono kolejno analizy jakościowe wypowiedzi dzieci oraz analizy ilościowe. Definicje zmiennych różnicujących wypowiedzi dzieci oraz podstawowe informacje na temat sposobu ich pomiaru zamieszczono w tych fragmentach tekstu, które ich dotyczą.

\footnotetext{
${ }^{6}$ M. Deptuła, Co uczniowie klas IV, V i VI chcieliby zmienić w swojej klasie? Swobodne wypowiedzi uczniów jako podstawa do wnioskowania o warunkach rozwoju psychospołecznego uczniów w relacjach z rówieśnikami, Przegląd Pedagogiczny, 2016, 2, s. 127-150.
} 


\section{Analizy jakościowe}

W analizach jakościowych wypowiedzi uczniów zastosowano metodę analizy treści, która wykorzystuje „zbiór systematycznych i obiektywnych procedur pozwalających na wyciąganie wniosków z tekstów"7. Dwóch sędziów kompletnych stworzyło kategorie analizy na podstawie:

- teorii z nurtu psychologii humanistycznej podkreślających znaczenie dla rozwoju człowieka poczucia akceptacji i szanowania go takim jakim jest ${ }^{8}$;

- psychologicznych teorii motywacji, z których wywodzą się pojęcia: potrzeba kontaktu emocjonalnego ${ }^{9}$, potrzeba szacunku i uznania oraz potrzeba bezpieczeństwa ${ }^{10}$;

- koncepcji klimatu społecznego szkoły, ze szczególnym naciskiem na cechy relacji społecznych ${ }^{11}$ oraz poczucie bezpieczeństwa fizycznego i emocjonalnego w szkole ${ }^{12}$;

- kryteriów oceny jakości życia dzieci i młodzieży (m.in. projekt KIDSCREEN), odnoszących się do takich obszarów funkcjonowania w szkole, jak: relacje z rówieśnikami, uczucia względem szkoły, akceptacja społeczna versus dręczenie przez rówieśników, poczucie akceptacji albo odrzucenia przez rówieśników ${ }^{13}$.

Następnie sędziowie, po wspólnej weryfikacji tych kategorii i stworzeniu klucza kodowego, dokonali, niezależnie od siebie, kategoryzacji a priori zebranego materiału badawczego. W wyniku tego procesu wypowiedziom uczniów przydzielono kody, grupując je w 10 kategoriach treściowych (zaprezentowanych w tabeli 2 i oznaczonych kodem cyfrowym), wyrażających ich potrzeby związane $\mathrm{z}$ relacjami z rówieśnikami oraz zachowaniami w klasie. Następnie przeprowadzono redukcję danych, w której brano pod uwagę frekwencję wypowiedzi przypisanych do danej kategorii. Jej wynikiem jest połączenie kategorii od 1 do 3 oraz nadanie kategoriom kodów literowych.

${ }^{7}$ K. Krejtz, I. Krejtz, Metoda analizy treści - teoria i praktyka badawcza, [w]: Wywiad psychologiczny. Wywiad jako postępowanie badawcze, red. K. Stemplewska-Żakowicz, K. Krejtz, Warszawa 2005, s. 130.

${ }^{8}$ C. Rogers, Sposób bycia, Poznań 2002; E. Fromm, O sztuce miłości, Poznań 2005.

${ }^{9}$ K. Obuchowski, Psychologia dążeń ludzkich, Warszawa 1983.

10 A. Maslow, Motywacja i osobowość, Warszawa 1990.

${ }^{11}$ C. Anderson, The Search for school climate, Review of Educational Research, 1982, 52(3), s. 368-420; M. Kulesza, Klimat szkoty a zachowania przemocowe uczniów.

12 W. Junik, Ewaluacja zasobów szkoły i diagnoza występujących w niej zagrożeń, [w]: Profilaktyka w grupach ryzyka. Część I - Diagnoza, red. M. Deptula, Warszawa 2009, s. 29-56; J. Cohen, V.K. Geier, School Climate Research Summary, New York, 2010 January. (www.scholclimate.org/ climate/research.php) [dostęp: 12.11.2018].

${ }_{13}$ M. Oleś, Jakość życia u dzieci i młodzieży - przegląd metod pomiaru, Przegląd Psychologiczny, 2010, 53, 2, s. 211-238, http://www.kul.pl/files/714/nowy_folder/2.53.2010_art.6.pdf [dostęp: 17.05 2019]; M. Oleś, Kryteria jakości życia młodzieży, Rocznik Filozoficzny Ignatianum, 2016, s. 114-129, https://czasopisma.ignatianum.edu.pl/index.php/rfi XXII / 1, [dostęp: 17.05.2019]. 
Tabela 2

Kategorie treściowe, do których zostały przypisane wypowiedzi uczniów i symbole zastosowane do ich opisu w dalszej analizie

\begin{tabular}{|c|c|c|c|c|}
\hline $\begin{array}{c}\text { Sym- } \\
\text { bol }\end{array}$ & $\begin{array}{l}\text { Kategorie } \\
\text { główne }\end{array}$ & Lp. & $\begin{array}{c}\text { Kategorie } \\
\text { szczegółowe }\end{array}$ & $\begin{array}{c}\text { Wskaźniki } \\
\text { - przykłady wypowiedzi } \\
\text { uczniów }^{14}\end{array}$ \\
\hline \multirow{3}{*}{ A } & \multirow{3}{*}{ 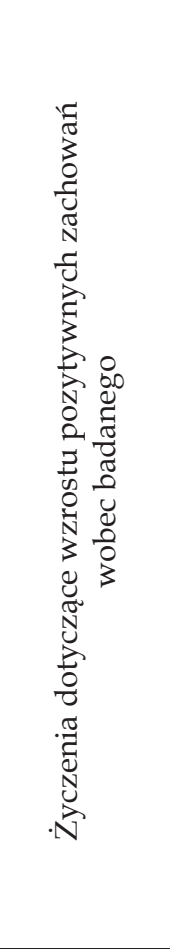 } & 1 & $\begin{array}{l}\text { Potrzeba akceptacji: } \\
\text { wyrażone pragnienie, } \\
\text { by być przyjmowa- } \\
\text { nym do pracy w gru- } \\
\text { pie, być lubianym. }\end{array}$ & $\begin{array}{l}\text { Chciałbym, aby więcej osób } \\
\text { mnie lubiło. } \\
\text { Chciałbym, żeby wiele osób } \\
\text { mnie lubiło, } \\
\text { żeby więcej osób przyjmowało } \\
\text { mnie chętnie do grupy. }\end{array}$ \\
\hline & & 2 & $\begin{array}{l}\text { Potrzeba szacunku: } \\
\text { wypowiedź świad- } \\
\text { cząca o pragnieniu, } \\
\text { by rówieśnicy słu- } \\
\text { chali wypowiedzi } \\
\text { badanego i liczyli się } \\
\text { z jego opinią. }\end{array}$ & $\begin{array}{l}\text { Chciałabym, aby ktoś zaintere- } \\
\text { sował się tym co ja lubię. } \\
\text { Chciałabym, żeby inni też wy- } \\
\text { słuchali moje zdanie (bo jeśli jest } \\
\text { jakaś ważniejsza osoba w klasie, } \\
\text { to tylko jej zdanie się liczy, a je- } \\
\text { śli ja chcę coś powiedzieć, to nie, } \\
\text { bo moje już będzie złe) i jest mi } \\
\text { z tego powodu smutno. } \\
\text { Chciałabym, aby moja koleżan- } \\
\text { ka mnie szanowała i żeby każdy } \\
\text { mnie traktował jak kolegę. }\end{array}$ \\
\hline & & 3 & $\begin{array}{l}\text { Potrzeba lepszego } \\
\text { kontaktu emocjonal- } \\
\text { nego z rówieśnikami } \\
\text { i wsparcia z ich } \\
\text { strony. }\end{array}$ & $\begin{array}{l}\text { Chciałabym, żeby wszyscy mi } \\
\text { pomagali w trudnych i smut- } \\
\text { nych chwilach. } \\
\text { A jeszcze smuci mnie to, że jeśli } \\
\text { coś mnie trapi, nikt się tym nie } \\
\text { interesuje. }\end{array}$ \\
\hline B & 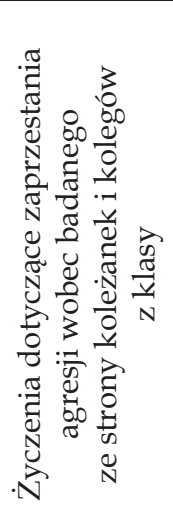 & 4 & $\begin{array}{l}\text { Potrzeba bezpieczeń- } \\
\text { stwa: wypowiedzi } \\
\text { świadczące o tym, } \\
\text { że badany jest ofiarą } \\
\text { agresji werbalnej lub } \\
\text { fizycznej i oczeki- } \\
\text { waniu, by sprawca } \\
\text { przemocy zmienił } \\
\text { swoje zachowanie i/ } \\
\text { lub poniósł konse- } \\
\text { kwencje. }\end{array}$ & $\begin{array}{l}\text { Żeby dziewczyna, która nam } \\
\text { dokucza poniosła za to konse- } \\
\text { kwencje. } \\
\text { Chciałabym zmienić zachowa- } \\
\text { nie dziewczyny, która dokucza } \\
\text { mi, moim koleżankom i mojej } \\
\text { przyjaciółce. } \\
\text { Chcę, żeby chłopacy mnie nie } \\
\text { przezywali, żeby inne osoby } \\
\text { mnie nie wyzywały, żeby ko- } \\
\text { ledzy z mojej klasy lepiej mnie } \\
\text { traktowali, żeby się nie śmiali ze } \\
\text { mnie, kiedy mi coś nie wyjdzie. }\end{array}$ \\
\hline
\end{tabular}

${ }^{14} \mathrm{~W}$ każdym przypadku zachowano oryginalną pisownię. 


\begin{tabular}{|c|c|c|c|c|}
\hline B & 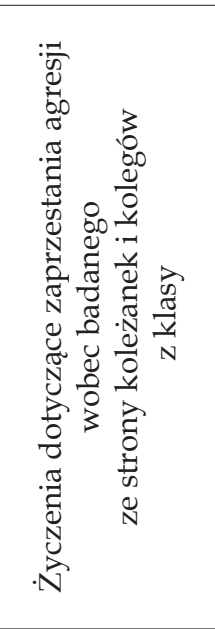 & 4 & & $\begin{array}{l}\text { Sama się dobrze czuję w mojej } \\
\text { klasie, mimo tego że mam tylko } \\
\text { dwie przyjaciółki, a reszta klasy } \\
\text { mnie nie lubi. Ale nie przeszka- } \\
\text { dza mi to, każdy może mieć } \\
\text { swoje zdanie o mnie, dla mnie } \\
\text { fajnie by było gdyby dało się } \\
\text { poprosić moją klasę o nie bicie, } \\
\text { wyzywanie mnie. } \\
\text { Chciałabym, żeby kilku chłopa- } \\
\text { ków z mojej klasy mi nie doku- } \\
\text { czało i też moim koleżankom, } \\
\text { czyli na przykład: nie wyzywali, } \\
\text { nie popychali, nie bili, nie prze- } \\
\text { klinali oraz nie kopali naszych } \\
\text { rzeczy. }\end{array}$ \\
\hline C & 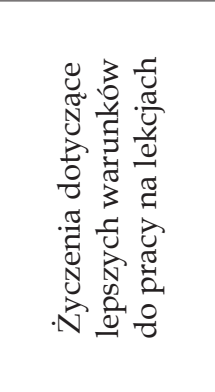 & 5 & $\begin{array}{l}\text { Potrzeba spokoju } \\
\text { i ciszy w czasie } \\
\text { lekcji: wypowiedzi } \\
\text { świadczące o tym, } \\
\text { że rówieśnicy swoim } \\
\text { zachowaniem na lek- } \\
\text { cjach przeszkadzają } \\
\text { badanemu, utrudnia- } \\
\text { ją skupienie i dener- } \\
\text { wują nauczycieli. }\end{array}$ & $\begin{array}{l}\text { Chcę zmienić hałas na ciszę. } \\
\text { Żeby chłopaki nie przeszkadzali } \\
\text { na lekcjach. } \\
\text { Bym chciał, żeby koledzy na } \\
\text { lekcjach nie rozmawiali, żeby } \\
\text { było cicho na lekcjach. }\end{array}$ \\
\hline D & 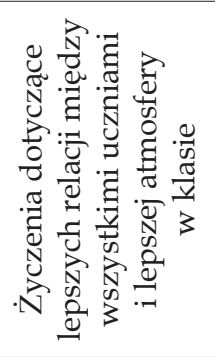 & 6 & $\begin{array}{l}\text { Potrzeba lepszego } \\
\text { kontaktu emocjonal- } \\
\text { nego i więzi w klasie: } \\
\text { wyrażone oczekiwa- } \\
\text { nia dotyczące wza- } \\
\text { jemnego szacunku } \\
\text { i pomocy oraz pra- } \\
\text { gnienie, aby wszyscy } \\
\text { byli szczęśliwi. }\end{array}$ & $\begin{array}{l}\text { Żeby wszyscy się lubili. Bardzo } \\
\text { bym chciała, żeby wszyscy się } \\
\text { akceptowali. } \\
\text { Chciałabym, żeby wszyscy się } \\
\text { lubili i szanowali. } \\
\text { Chciałabym, żeby mieli większy } \\
\text { szacunek do mało sławnych, } \\
\text { żeby wszyscy byli dla siebie mili } \\
\text { i tolerancyjni. }\end{array}$ \\
\hline $\mathrm{E}$ & 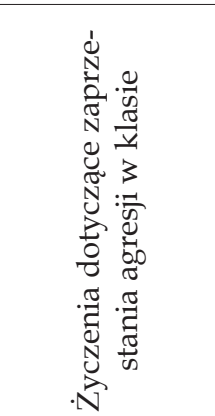 & 7 & $\begin{array}{l}\text { Potrzeba bezpie- } \\
\text { czeństwa fizycznego } \\
\text { i psychicznego, } \\
\text { której wyrazem są } \\
\text { wypowiedzi doty- } \\
\text { czące zaprzestania } \\
\text { agresji w każdej } \\
\text { postaci w życiu klasy: } \\
\text { życzenia, by w klasie } \\
\text { uczniowie nie }\end{array}$ & $\begin{array}{l}\text { Żeby się nie bili, nie przezywali. } \\
\text { Chciałabym, żeby nikt nie prze- } \\
\text { klinał i nie robił sobie na złość. } \\
\text { Żeby, więcej osób akceptowa- } \\
\text { ło inne osoby; nie za to, że są } \\
\text { np. bogate albo ładne. Dużo } \\
\text { w naszej klasie się kłócimy albo } \\
\text { się wkurzamy na inne osoby, } \\
\text { ponieważ np. ktoś się nazwał } \\
\text { CYCKIEM. }\end{array}$ \\
\hline
\end{tabular}




\begin{tabular}{|c|c|c|c|c|}
\hline $\mathrm{E}$ & 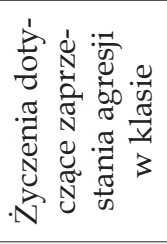 & 7 & $\begin{array}{l}\text { przeklinali, nie bili } \\
\text { się, nie kłócili się, nie } \\
\text { przezywali się, nie } \\
\text { dokuczali sobie itp. }\end{array}$ & $\begin{array}{l}\text { Chciałbym, żeby niektóre osoby } \\
\text { były mniej agresywne, a byli dla } \\
\text { siebie milsi. } \\
\text { Żeby nikt sobie nie dokuczał, } \\
\text { żeby nikt nie był odrzucany, } \\
\text { nikt się nie bił. }\end{array}$ \\
\hline $\mathrm{F}$ & 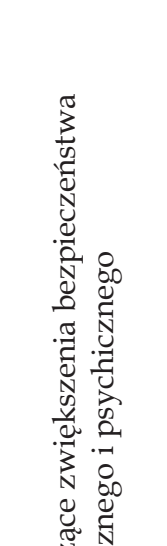 & 8 & $\begin{array}{l}\text { Potrzeba bezpie- } \\
\text { czeństwa fizycznego } \\
\text { i psychicznego: wy- } \\
\text { powiedzi dotyczące } \\
\text { poczucia zagrożenia } \\
\text { na przerwach z po- } \\
\text { wodu gry w piłkę } \\
\text { przez chłopców, bie- } \\
\text { gania i przepychania } \\
\text { się przy ustawianiu } \\
\text { się oraz wypowiedzi } \\
\text { świadczące o potrze- } \\
\text { bie zaufania komuś } \\
\text { w klasie. }\end{array}$ & $\begin{array}{l}\text { Żeby chłopcy się nie popychali } \\
\text { przy ustawianiu przed klasą. } \\
\text { (...) żebym mógł komuś zaufać. }\end{array}$ \\
\hline $\mathrm{G}$ & 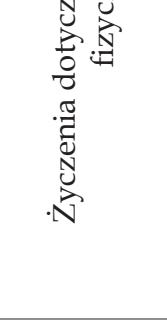 & 9 & $\begin{array}{l}\text { Żądanie wykluczenia } \\
\text { z zespołu klasowego } \\
\text { ucznia bądź uczniów, } \\
\text { których zachowanie } \\
\text { jest nieakceptowane, } \\
\text { uciążliwe dla innych, } \\
\text { stanowi źródło złego } \\
\text { samopoczucia. }\end{array}$ & $\begin{array}{l}\text { Chciałbym, żeby (tu imię chłop- } \\
\text { ca) zmienił szkołę. } \\
\text { Wypędzić (tu imię chłopca) }\end{array}$ \\
\hline $\mathrm{H}$ & 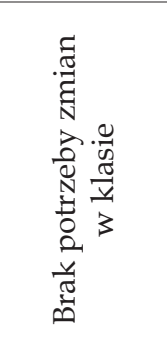 & 10 & $\begin{array}{l}\text { Akceptacja klasy } \\
\text { i swojej w niej sy- } \\
\text { tuacji: wypowiedzi } \\
\text { o braku potrzeby } \\
\text { zmian, o pozytyw- } \\
\text { nym stosunku emo- } \\
\text { cjonalnym do klasy. }\end{array}$ & $\begin{array}{l}\text { Ja nie chcę zmieniać nic w mo- } \\
\text { jej klasie, moim zdaniem moja } \\
\text { klasa jest super! } \\
\text { Ja nic nie chcę w mojej klasie } \\
\text { zmienić, dobrze czuję się w tej } \\
\text { klasie, mam najmilszą panią na } \\
\text { świecie i fajne koleżanki i kole- } \\
\text { gów. } \\
\text { Nic }\end{array}$ \\
\hline
\end{tabular}

Przedstawione $\mathrm{w}$ tabeli kategorie wypowiedzi uczniów odnoszą się do dwóch wątków. Pierwszy dotyczy indywidualnych doświadczeń związanych z funkcjonowaniem w zespole klasowym. Życzenia w tym zakresie mają bardzo osobisty charakter i są wyrazem potrzeby zmiany traktowania badanego ucznia przez inne osoby w klasie. Wyodrębniono w nich te, które wyrażają pragnienie większej akceptacji, szacunku, kontaktu emocjonalnego i wspar- 
cia (kategoria A). Do drugiej grupy (B) zaliczono skargi na doświadczanie przemocy i życzenia jej przerwania oraz ukarania sprawców. Zdarzyły się także wypowiedzi wskazujące na poczucie zagrożenia z powodu zachowania konkretnej osoby $\mathrm{w}$ klasie, co $\mathrm{w}$ kilku przypadkach przejawiło się w żądaniu wykluczenia tej osoby z klasy (kategoria G). Zgodnie z wiedzą na temat warunków rozwoju psychospołecznego dzieci i młodzieży, przeżycia tego typu negatywnie wpływają na samopoczucie i zdrowie psychiczne uczniów, poczucie własnej wartości, jak też na wyniki w nauce ${ }^{15}$.

Drugi wątek odnosi się do klimatu społecznego klasy i zawiera również dwa rodzaje wypowiedzi. Jeden wskazuje na chęć poprawy więzi łączących uczniów w klasie, czego wyrazem są wypowiedzi sformułowane w postaci pozytywnych życzeń, których adresatem są wszystkie osoby chodzące do jednej klasy. Dotyczą one między innymi dobrego zdrowia, szczęścia, wzajemnej akceptacji i tolerancji, pomagania sobie, okazywania życzliwości. Następny nurt stanowią wypowiedzi wyrażające potrzebę zaprzestania danego zachowania $w$ klasie. Uczniowie piszą między innymi o agresji werbalnej i fizycznej, nieostrożności i konieczności wykluczenia z klasy uczniów, których zachowania są dla nich uciążliwe, zagrażające. Na spostrzegany przez uczniów klimat społeczny klasy, który odzwierciedla przeżywaną przez nich rzeczywistość szkolną, mają wpływ doświadczenia, przekonania, wartości, płeć oraz inne czynniki związane $\mathrm{z}$ warunkami życiowymi ${ }^{16}$. W celu pogłębienia wiedzy na temat uczniów, którzy zgłosili życzenia dotyczące zmian w swojej klasie, zostały przeprowadzone analizy ilościowe zebranego materiału badawczego.

\section{Analizy ilościowe}

Ze względu na to, że wypowiedzi części uczniów zawierały kilka wątków mieszczących się w różnych kategoriach, w dalszych analizach $100 \%$ stanowi zawsze liczba wypowiedzi danej grupy badanych. Rozkłady procentowe omawiane są zgodnie $\mathrm{z}$ wyodrębnionymi kategoriami treści, oznaczonymi kodami literowymi. Z uwagi na niewystarczającą liczbę przypadków do analizowania istotności różnic między porównywanymi grupami badanych z uwzględnieniem 8 kategorii, do analizy statystycznej

${ }^{15}$ M. Deptuła, A. Potorska, Sz. Borsich, Wczesna profilaktyka w rozwoju psychospołecznym i zachowań ryzykownych, Warszawa 2018; M. Deptuła, Odrzucenie rówieśnicze.

${ }^{16}$ M. Kulesza, Klimat szkoły a zachowania przemocowe uczniów; K. Ostaszewski, Kluczowe elementy pozytywnej profilaktyki: wspieranie konstruktywnych relacji międzyludzkich w środowiskach dojrzewania, [w:] Zachowania ryzykowne młodzieży w perspektywie mechanizmów resilience, Warszawa 2014, s. 134-148; A. Kołakowski, Budowanie ustrukturyzowanego i przyjaznego środowiska w klasie, [w:] Zaburzenia psychiczne i rozwojowe u dzieci a szkolna rzeczywistość, red. M. Jerzak, Warszawa 2016, s. 417-428. 
za pomocą testu Chi-kwadrat ${ }^{17}$ łączono dane $\mathrm{z}$ poszczególnych kategorii w sposób podany w tabeli 3 .

Tabela 3

Łączenie danych z poszczególnych kategorii jakościowych do analiz istotności różnic między porównywanymi grupami badanych

\begin{tabular}{|l|c|c|}
\hline \multicolumn{1}{|c|}{ Rodzaj porównania } & $\begin{array}{c}\text { Dane łączone } \\
\text { w jedną grupę }\end{array}$ & $\begin{array}{c}\text { Dane stanowiące } \\
\text { drugą grupę } \\
\text { lub łączone w jedną grupę }\end{array}$ \\
\hline $\begin{array}{l}\text { Życzenia dotyczące } \\
\text { pożądanych zmian versus } \\
\text { życzenia dotyczące utrzy- } \\
\text { mania status quo }\end{array}$ & A, B, C, D, E, F, G & $\mathrm{H}$ \\
\hline $\begin{array}{l}\text { Życzenia dotyczące } \\
\text { wzrostu pozytywnych } \\
\text { zachowań wobec badanego } \\
\text { i w klasie versus życzenia } \\
\text { dotyczące zaprzestania } \\
\text { agresji }\end{array}$ & A, C, D & B, E, F, G \\
\hline
\end{tabular}

W przypadku pierwszego porównania sens łączenia kategorii wyrażających potrzebę zmiany nie wymaga uzasadnienia. W wypadku porównań drugiego rodzaju, za połączeniem kategorii B, E, F i G przemawia fakt, że wypowiedzi w nich zawarte dotyczą jakiejś formy agresji i zagrożenia poczucia bezpieczeństwa.

\section{Życzenia dotyczące zmian w klasie wyrażane przez badanych uczniów na początku i na końcu roku szkolnego}

Częstotliwość wypowiedzi uczniów na temat pożądanych zmian w zespole klasowym w I i II pomiarze przedstawiono w tabeli 4.

${ }_{17}$ Warunkiem poprawności analizy za pomocą testu Chi-kwadrat jest, aby liczebności oczekiwane (teoretyczne) wszystkich pól w tabelach 2 × 2 nie były mniejsze od 5, a w przypadku tabel o liczbie pól większej niż 4 dopuszcza się, by liczebności oczekiwane od 1 do 4 nie występowały w więcej niż $20 \%$ pól tabeli; por. J. Brzeziński, Metodologia badań psychologicznych, Warszawa 1996. Testem tym przeprowadzono wszystkie analizy istotności różnic między porównywanymi grupami prezentowane $\mathrm{w}$ niniejszym artykule. 
Częstotliwość wypowiedzi

Tabela 4

w poszczególnych kategoriach treściowych w I i II pomiarze

\begin{tabular}{|c|c|c|c|c|c|c|c|c|c|c|}
\hline \multirow{2}{*}{$\begin{array}{l}\text { Po- } \\
\text { miar }\end{array}$} & \multirow{2}{*}{$\begin{array}{c}\mathrm{N} / \\
\%\end{array}$} & \multicolumn{9}{|c|}{ Symbol kategorii treści } \\
\hline & & $\mathrm{A}$ & B & $\mathrm{C}$ & $\mathrm{D}$ & E & $\mathrm{F}$ & G & $\mathrm{H}$ & $\begin{array}{l}\text { Ra- } \\
\text { zem }\end{array}$ \\
\hline \multirow{2}{*}{ I } & $\mathrm{N}$ & 20 & 12 & 21 & 34 & 12 & 7 & 0 & 39 & 145 \\
\hline & $\%$ & 13,8 & 8,3 & 14,5 & 23,4 & 8,3 & 4,8 & & 26,9 & 100 \\
\hline \multirow{2}{*}{ II } & $\mathrm{N}$ & 16 & 25 & 15 & 42 & 20 & 0 & 5 & 30 & 153 \\
\hline & $\%$ & 10,5 & 16,3 & 9,8 & 27,5 & 13,1 & & 3,3 & 19,6 & 100,1 \\
\hline
\end{tabular}

W I pomiarze najwyższy odsetek wypowiedzi uczniów wyrażał zadowolenie z takiej klasy jaką ona jest, jednak w II pomiarze był on już o 7,3\% niższy. Różnice pomiędzy liczbą wypowiedzi wyrażających zadowolenie z tego jaka klasa jest a liczbą wypowiedzi dotyczących oczekiwanych zmian w obu pomiarach są nieistotne statystycznie. W przytaczanych w tym artykule badaniach M. Deptuły z roku 2016 uczniowie, którzy niczego nie chcieli zmieniać w swojej klasie stanowili tylko 9,7\% badanych.

Na początku klasy IV blisko 1/4 wypowiedzi dotyczyła potrzeby większej więzi w klasie, wzajemnej pomocy, kultury osobistej (kategoria D). Zbliżone odsetki wypowiedzi uczniów sygnalizowały potrzeby większej akceptacji, szacunku, nawiązania kontaktu emocjonalnego, uznania i wzajemnego wsparcia ze strony rówieśników (kategoria A) oraz potrzebę ciszy na lekcjach i sprawdzianach (kategoria C). Wypowiedzi dzieci w II pomiarze świadczą o wzrastającym zapotrzebowaniu na dobrą atmosferę w klasie i lepsze relacje między uczniami (kategoria D) oraz o narastaniu problemu agresji fizycznej, werbalnej i dokuczania przez rówieśników (kategoria B i E). Odsetek wypowiedzi dotyczących zaprzestania agresji wymierzonej w wypowiadające się dziecko (kategoria B) jest nieco wyższy niż wypowiedzi dotyczących agresji w klasie (kategoria E). Różnice w tym zakresie - częstotliwości życzeń dotyczących wzrostu zachowań pożądanych (kategorie A, C, D) i spadku zachowań zagrażających poczuciu bezpieczeństwa fizycznego i psychicznego (kategorie B, E, F, G) - w I i II pomiarze są nieistotne statystycznie, ale w II pomiarze odnotowano wyniki bliskie wartości krytycznej (wartość Chi-kwadrat $=3,240$, df $=1, \mathrm{p}=0,072$, wartość krytyczna dla $\mathrm{p}=0,05$ wynosi 3,841).

W projekcie uczestniczyło 9 zespołów klasowych, w których wychowawca klasy i wybrany przez niego nauczyciel języka polskiego, matematyki lub języka angielskiego współpracowali z autorami i realizatorami pro- 
jektu „Niebieskoocy” w naszej szkole... (grupa N) oraz 8 zespołów klasowych, $\mathrm{w}$ których tylko przeprowadzano pomiary tych samych zmiennych $\mathrm{w}$ ten sam sposób, a wyniki udostępniano wychowawcy klasy $\mathrm{w}$ formie prezentacji w programie PowerPoint wraz z sugestiami dotyczącymi celów pracy z klasą (grupa P). Przed przystąpieniem do dalszych analiz sprawdzono, czy występują istotne różnice między tymi grupami w zakresie częstotliwości wypowiedzi na temat pożądanych przez uczniów zmian w zespole klasowym i wypowiedzi dotyczących utrzymania status quo. W pomiarze I odsetek wypowiedzi świadczących o zadowoleniu z tego, jaka klasa jest był znacznie wyższy w grupie N. W drugim pomiarze odsetek wypowiedzi w tej kategorii był w obu grupach zbliżony, ponieważ w grupie $\mathrm{N}$ odnotowano w tej kategorii spadek o prawie 20 punktów procentowych. Różnice między wypowiedziami wyrażającymi potrzebę zmian w klasie oraz brak potrzeby zmian w I pomiarze są istotne statystycznie (Chi-kwadrat $=6,015$, $\mathrm{df}=1, \mathrm{p}<0,02$; wartość krytyczna Chi-kwadrat na tym poziomie 5,412). W II pomiarze różnice między grupami $\mathrm{N}$ i P są nieistotne statystycznie.

$\mathrm{W}$ analizach drugiego rodzaju dotyczących życzeń wzrostu pozytywnych zachowań wobec badanego i w klasie (kategorie A, C, D) versus życzeń odnoszących się do zaprzestania agresji wobec badanego i w klasie (B, E, F, $\mathrm{G})$ nie stwierdzono istotnych różnic pomiędzy grupą $\mathrm{N}$ i P ani w I, ani w II pomiarze. Nie można więc powiedzieć, aby przynależność klasy do grupy N lub P istotnie różnicowała treści wypowiedzi badanych, bowiem współpraca $\mathrm{z}$ nauczycielami $\mathrm{w}$ projekcie rozpoczęła się po I pomiarze. Pozwala to dalej analizować wypowiedzi uczniów z obydwu grup w każdym z pomiarów łącznie.

\section{Życzenia dotyczące zmian w klasie wyrażane przez dziewczęta i chłopców}

Jak obrazuje to rycina $1, \mathrm{w}$ obydwu pomiarach odsetek wypowiedzi chłopców zadowolonych ze swojej klasy (kategoria $\mathrm{H}$ ) był wyższy aniżeli dziewcząt. W I pomiarze różnica wynosiła 10 punktów procentowych, w drugim odsetki zarówno w grupie dziewcząt jak i chłopców spadły, ale blisko 10-punktowa różnica się utrzymała. Wyniki testu wskazują, że w pierwszym pomiarze chłopcy częściej niż dziewczęta wyrażali zadowolenie z tego, jaka klasa jest (Chi-kwadrat $=7,747, \mathrm{df}=1, \mathrm{p}<0,005)$, a różnice między tymi grupami są istotne statystycznie. W II pomiarze różnice $w$ tym zakresie między chłopcami i dziewczętami są statystycznie nieistotne. 


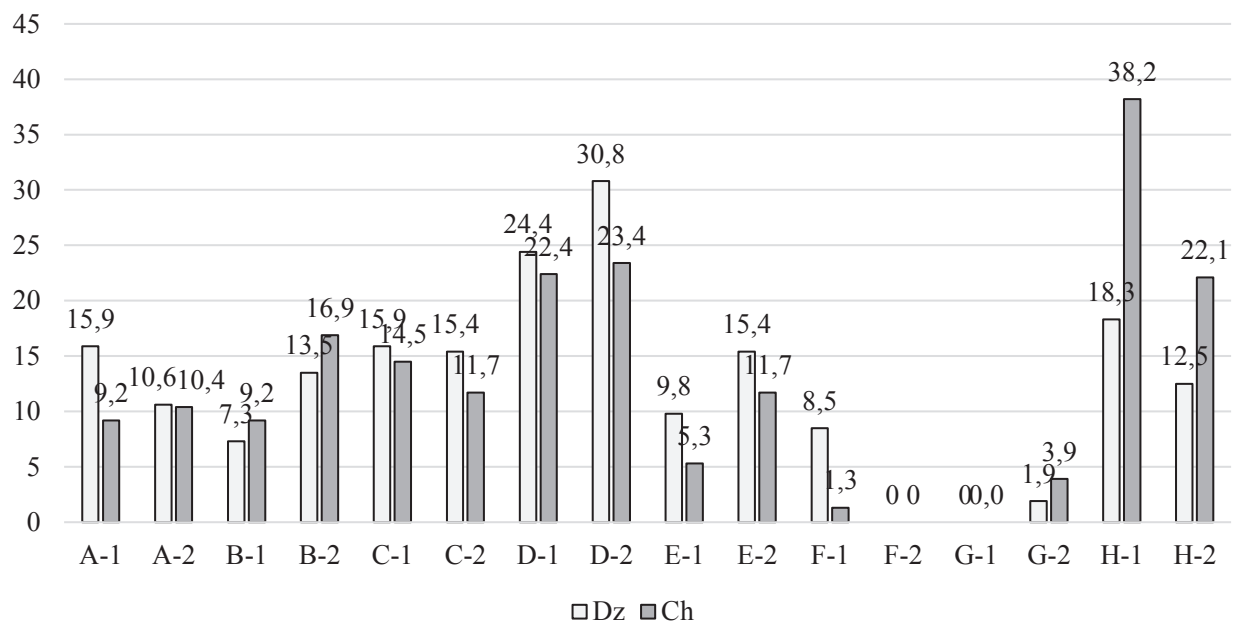

Ryc. 1. Odsetek wypowiedzi uczniów w I i II pomiarze na temat pożądanych zmian w klasie w grupie dziewcząt i chłopców

Legenda:

- życzenia dotyczące zmian w odniesieniu do badanego dziecka: A - wzrostu pozytywnych zachowań (akceptacji, szacunku, wsparcia), B - zaprzestania agresji;

- życzenia dotyczące zmian w klasie: C - lepszych warunków do pracy na lekcjach (cisza, nieprzeszkadzanie), D - lepszej atmosfery i lepszych relacji między uczniami (większej więzi w klasie, wzajemnej pomocy, kultury osobistej), E - zaprzestania/zmniejszenia agresji, F - zwiększenia bezpieczeństwa fizycznego i psychicznego, G - żądanie wykluczenia danego ucznia z klasy; - odpowiedzi wskazujące na zadowolenie z klasy takiej, jaką jest - H

Biorąc pod uwagę rodzaj postulowanych zmian (wypowiedzi dotyczące większej akceptacji, lepszej atmosfery w klasie, czy ciszy na lekcjach vs wypowiedzi dotyczące zaprzestania agresji w każdej postaci), można powiedzieć, że dziewczęta częściej niż chłopcy sygnalizowały potrzebę lepszej atmosfery w klasie (kategoria D). W pomiarze I różnica między dziewczętami i chłopcami nie była duża, ale pomiędzy I a II pomiarem odsetek takich wypowiedzi w grupie dziewcząt wzrósł o 5,6 punktów procentowych, a odsetek wypowiedzi chłopców prawie się nie zmienił. W rezultacie odsetek życzeń dziewcząt jest w tej kategorii w II pomiarze wyższy o ponad 7 punktów procentowych. W I pomiarze dziewczęta nieco częściej niż chłopcy wyrażały potrzebę większej akceptacji, szacunku dla siebie i wsparcia (kategoria A). W II pomiarze częstotliwość wypowiedzi na ten temat jest $\mathrm{w}$ obu grupach prawie taka sama. W kategoriach dotyczących wzrostu pożądanych zachowań (A, C i D) częstotliwość wypowiedzi była w grupie dziewcząt w I pomiarze wyższa niż w grupie chłopców o nieco ponad 10 punktów procentowych, a w II pomiarze o nieco ponad 11 punktów procentowych. 
W I pomiarze $\mathrm{w}$ kategoriach zawierających wypowiedzi dotyczące doświadczania poczucia zagrożenia z powodu nieostrożności kolegów (kategoria $\mathrm{F}$ ), bycia ofiarą agresji (kategoria B) lub obserwowania jej w klasie (kategoria E) było więcej wypowiedzi dziewcząt (o 5,8 punktów procentowych). W pomiarze II różnice te są nieznaczne; nieco wyższy jest odsetek chłopców. Warto zwrócić uwagę na to, że $\mathrm{w}$ obu grupach nastąpił wzrost $\mathrm{w}$ tym zakresie - w grupie dziewcząt tylko o 5,2 punktu procentowego, ale w grupie chłopców aż o 12,7. Zgromadzone dane nie pozwalają na stwierdzenie, co jest przyczyną tego wzrostu - czy zachowania zakłócające poczucie bezpieczeństwa nasiliły się w badanych zespołach uczniów, czy też zmniejszyła się tolerancja dla nich.

Analiza różnic między dziewczętami i chłopcami w zakresie formułowania życzeń dotyczących wzrostu pozytywnych zachowań wobec badanego i w klasie (kategorie A, C, D) oraz życzeń dotyczących zaprzestania agresji i zachowań zagrażających poczuciu bezpieczeństwa (kategorie B, E, F, G) prowadzi do wniosku, że są one nieistotne statystycznie ani w I, ani w II pomiarze.

\section{Życzenia dotyczące zmian w klasie wyrażane przez młodszych i starszych uczniów}

Jak podano w tabeli 1, w badanej próbie znajdowali się uczniowie, którzy rozpoczęli naukę w wieku 7 lat oraz rok młodsi. Zbliżony odsetek uczniów $\mathrm{z}$ obu tych grup udzielił odpowiedzi na pytanie otwarte. Interesujące było ustalenie, czy występują między nimi różnice w zakresie poruszanych problemów.

Częstotliwość wyrażania zadowolenia ze status quo istniejącego w klasie i formułowania życzeń dotyczących zmian zarówno w I pomiarze, jak i w II nie zależy od wieku wypowiadających się uczniów. Jeśli chodzi natomiast o zróżnicowanie treści wypowiedzi dotyczących pożądanych zmian, to w I pomiarze widoczne są różnice pomiędzy starszymi i młodszymi uczniami w zakresie częstotliwości zgłaszania potrzeby akceptacji, szacunku i wsparcia ze strony kolegów i koleżanek z klasy (odsetek takich wypowiedzi jest w grupie urodzonych w roku 2008 o 6,3 punktu procentowego wyższy) oraz potrzeby lepszej atmosfery w klasie (odsetek wypowiedzi o 4,2). Starsi uczniowie znacznie częściej niż młodsi zgłaszali problem występowania agresji w klasie (kategoria E1, odsetek o 9,4 wyższy).

W II pomiarze więcej wypowiedzi dzieci, które poszły do szkoły w wieku 6 lat dotyczyło doświadczania różnych form agresji ze strony rówieśników. Wypowiedzi w kategorii B jest w tej grupie o 4,1 punktu procentowego 


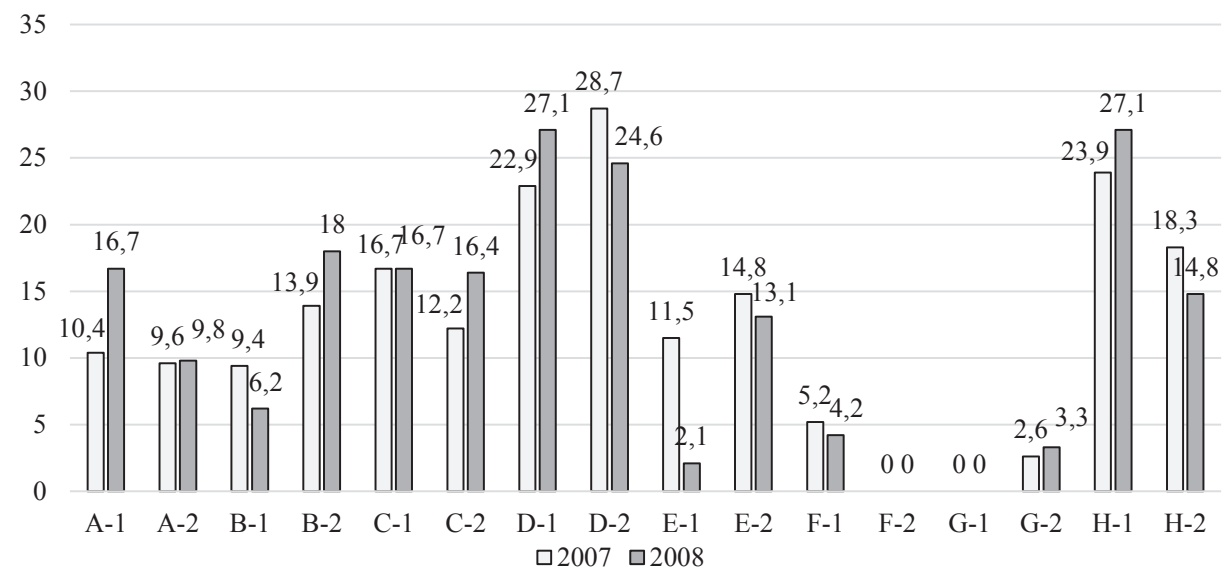

Ryc. 2. Odsetek wypowiedzi uczniów w I i II pomiarze

na temat pożądanych zmian w klasie w grupie młodszych i starszych uczniów

Legenda:

- życzenia dotyczące zmian w odniesieniu do badanego dziecka: A - wzrostu pozytywnych zachowań (akceptacji, szacunku, wsparcia), B - zaprzestania agresji;

- życzenia dotyczące zmian w klasie: C - lepszych warunków do pracy na lekcjach (cisza, nieprzeszkadzanie), D - lepszej atmosfery i lepszych relacji między uczniami (większej więzi w klasie, wzajemnej pomocy, kultury osobistej), E - zaprzestania/zmniejszenia agresji, F - zwiększenia bezpieczeństwa fizycznego i psychicznego, G - żądanie wykluczenia danego ucznia z klasy;

- odpowiedzi wskazujące na zadowolenie z klasy takiej, jaką jest - H

więcej niż w grupie rozpoczynających naukę w wieku 7 lat. Natomiast starsze dzieci częściej życzą sobie lepszej atmosfery w klasie (różnica o 4,1pkt.). Różnice w zakresie częstotliwości zgłaszania życzeń dotyczących wzrostu pozytywnych zachowań wobec badanego oraz w klasie (kategorie A, C, D) vs częstotliwości zgłaszania życzeń dotyczących zaprzestania agresji wobec badanego i w klasie (kategorie B, E, F, G) są w obu pomiarach nieistotne statystycznie.

\section{Życzenia dotyczące zmian w klasie wyrażane przez uczniów przypisanych do trzech grup ze względu na poziom ryzyka vs ochrony przed problemami w rozwoju psychospołecznym i zachowaniami ryzykownymi}

Niżej prezentowane porównania dotyczące częstotliwości zgłaszania przez uczniów określonych problemów czy życzeń odnoszą się do następujących czynników różnicujących sytuację dziecka w klasie szkolnej, jak: 
- warunki rozwoju psychospołecznego w relacjach z rówieśnikami;

- stres odczuwany w związku ze szkołą i nauką;

- stosunek emocjonalny do szkoły.

W celu utworzenia grup zróżnicowanych ze względu na poziom każdego z tych czynników wyznaczono, zgodnie z procedurą stosowaną w badaniach z zakresu profilaktyki zachowań ryzykownych dzieci i młodzieży, grupę uczniów, których wynik na danej skali można uznać za czynnik ryzyka, wynik typowy, czynnik chroniący ${ }^{18}$. Przyjęto, że czynniki ryzyka to właściwości indywidulane, cechy środowiska rodzinnego, rówieśniczego, najbliższego otoczenia społecznego oraz środowiska makrospołecznego, które mają związek z występowaniem zachowań ryzykownych, chorób i zaburzeń zdrowia psychicznego ${ }^{19}$. W ujęciu statystycznym są to korelaty albo predyktory zaburzeń zachowania i zdrowia psychicznego. Natomiast, za czynniki chroniące uznaje się te właściwości indywidulane, cechy środowiska rodzinnego, rówieśniczego, najbliższego otoczenia społecznego oraz środowiska makrospołecznego, które wzmacniają zdrowie i pozytywne funkcjonowanie jednostki ${ }^{20}$. Inaczej mówiąc, zmniejszają lub neutralizują negatywne efekty działania czynników ryzyka ${ }^{21}$.

Ze względu na sposób pomiaru zmiennych zastosowano dwie odmienne procedury wyznaczania wymienionych wyżej grup.

W przypadku zmiennej warunki rozwoju psychospołecznego w relacjach z rówieśnikami, które badano odpowiednio na skali porządkowej, do wyodrębniania wyżej wymienionych trzech grup badanych zastosowano kwartyle i nadano wynikowi każdego dziecka kod. Kodem 1 (czynnik ryzyka) oznaczono wynik tych badanych, których rezultat uzyskany w zakresie danej skali mieścił się w kwartylu dolnym, co oznacza około $25 \%$ najniższych wyników w badanej próbie. Kodem 2 (wynik typowy) oznaczono wyniki mieszczące się w 2 i 3 kwartylu, co oznacza około 50\% wyników. Kodem 3 (czynnik chroniący) oznaczono wyniki znajdujące się w kwartylu górnym.

W przypadku pozostałych zmiennych przyjęto inne rozwiązania, prezentowane w poświęconych im częściach tego artykułu.

${ }^{18}$ K. Ostaszewski, Zachowania ryzykowne młodzieży w perspektywie mechanizmów resilience, Warszawa 2014.

19 Tamże; K. Ostaszewski, Czynniki ryzyka i czynniki chroniace w zachowaniach ryzykownych, s. $19-45$.

${ }^{20}$ K. Ostaszewski, Zachowania ryzykowne młodzieży; tenże, Czynniki ryzyka i czynniki chroniace w zachowaniach ryzykownych, s. 19-45.

${ }^{21}$ S.S. Luthar, Resilience in development, s. 740-795; A.S. Masten, J.L. Powell, A Resilience Framework for Research Policy and Practice, [w:] Resilience and Vulnerability, red. S.S. Luthar, Cambridge 2003, s. 1-28. 


\section{Warunki rozwoju psychospołecznego w relacjach z rówieśnikami a formułowane przez uczniów życzenia dotyczące zmian w klasie}

Warunki rozwoju psychospołecznego stanowią fragment społecznego kontekstu rozwoju jednostki odnoszący się do relacji z rówieśnikami. Założono, że o warunkach rozwoju psychospołecznego można wnioskować przez pryzmat możliwości zaspokojenia $\mathrm{w}$ danym środowisku, $\mathrm{w}$ tym przypadku w klasie szkolnej, potrzeby bezpieczeństwa, kontaktu emocjonalnego i więzi, autonomii i sprawstwa. Anna Brzezińska nazywa je warunkami niespecyficznymi, bo istotnymi przez całe życie człowieka ${ }^{22}$. Drugim kryterium oceny jest możliwość realizacji zadania życiowego przypadającego na dany okres rozwoju, zgodnie z koncepcją Erika H. Eriksona ${ }^{23}$. Warunki z tym związane Brzezińska nazywa specyficznymi ${ }^{24}$, bowiem są one szczególnie ważne w danym okresie życia. W przypadku uczniów w klasach IV-VI jest to zadanie budowania poczucia kompetencji ${ }^{25}$, dla którego szczególne znaczenie ma poczucie bycia docenianym przez znaczące osoby dorosłe i rówieśników, doświadczanie ich wsparcia oraz odnoszenie sukcesów w nauce i relacjach z rówieśnikami. Wskaźnikiem warunków rozwoju psychospołecznego w relacjach z rówieśnikami są w prezentowanym tu badaniu odpowiedzi ucznia na 21 pytań odnoszących się do jego doświadczeń i przekonań dotyczących tego, jak traktują go lub jak mogliby się wobec niego zachować rówieśnicy z klasy szkolnej w podanych sytuacjach. Za Augustynem Bańką ${ }^{26}$ przyjęto, że zależność między człowiekiem i środowiskiem można analizować przez pryzmat jego wewnętrznego doświadczenia - percepcji, odczuć, emocji, motywacji, wartości. „Indywidualne mechanizmy odbioru środowiska nadają mu określone znaczenia, a te z kolei wyznaczają kierunek aktywności człowieka". Relacje badanych na temat rzeczywistych i możliwych zachowań rówieśników w typowych sytuacjach szkolnych formułowane są na bazie wcześniejszych doświadczeń, wyniesionych nie tylko z tej klasy, bowiem w przewidywaniu i interpretowaniu cudzych zachowań korzystamy z teorii umysłu tworzonej przez całe życie, ale to ona właśnie wyznacza w znacznym stopniu zachowania człowieka ${ }^{27}$.

${ }^{22}$ A.I. Brzezińska, Jak przebiega rozwój człowieka? [w:] Psychologiczne portrety człowieka. Praktyczna psychologia rozwojowa, red. A Brzezińska, Gdańsk 2005, s. 21-39.

${ }^{23}$ E.H. Erikson. Dzieciństwo i społeczeństwo, Poznań 1997.

${ }^{24}$ A.I. Brzezińska, Jak przebiega rozwój człowieka? s. 21-39.

${ }^{25}$ E.H. Erikson. Dzieciństwo i społeczeństwo; B. Smykowski Psychologia kryzysów w kulturowym rozwoju dzieci i młodzieży, Poznań 2012.

26 A. Bańka, Społeczna psychologia środowiskowa, Warszawa 2002.

27 H.R. Schaffer, Psychologia rozwojowa. Podstawowe pojęcia, Kraków 2006; tenże, Rozwój społeczny. Dzieciństwo i młodość, Kraków 2006. 
Przykładowe pytania $\mathrm{w}$ zastosowanej ankiecie dotyczące tej zmiennej brzmiały: Jak myślisz, ile osób z Twojej klasy przestałoby robić coś, co Ci się nie podoba, gdybyś powiedział (a) im, że to Ci nie pasuje? Ile osób w Twojej klasie cieszy się razem z Toba, kiedy odnosisz sukces? Opcje odpowiedzi: nikt, jedna osoba, kilka osób, wiele osób, prawie wszyscy ${ }^{28}$. Średni wynik na skali do badania tej zmiennej mieści się w przedziale od 0 do 4 punktów. Wartości graniczne dla grup wyodrębnionych ze względu na poziom ryzyka vs ochrony przedstawiono w tabeli 5.

Tabela 5

Wartości graniczne dla zaliczania wyników badanych uczniów do trzech grup w zależności od ryzyka związanego z warunkami rozwoju psychospołecznego $\mathrm{w}$ relacjach $\mathrm{z}$ rówieśnikami

\begin{tabular}{|c|c|c|c|c|c|c|}
\hline \multirow{2}{*}{$\begin{array}{c}\text { Zmien- } \\
\text { na }\end{array}$} & \multicolumn{3}{|c|}{ Wartości dla poszczególnych grup } & \multicolumn{3}{|c|}{ Wartości dla poszczególnych grup } \\
ny I pomiarze & $\begin{array}{c}\text { czynnik } \\
\text { ryzyka }\end{array}$ & $\begin{array}{c}\text { wynik } \\
\text { typowy }\end{array}$ & $\begin{array}{c}\text { czynnik } \\
\text { chroniący }\end{array}$ & $\begin{array}{c}\text { czynnik } \\
\text { ryzyka }\end{array}$ & $\begin{array}{c}\text { wynik } \\
\text { typowy }\end{array}$ & $\begin{array}{c}\text { czynnik } \\
\text { chroniący }\end{array}$ \\
\hline $\begin{array}{c}\text { Relacje } \\
\text { z rówie- } \\
\text { śnikami }\end{array}$ & $0<=\mathrm{x}<1,91$ & $1,91<=\mathrm{x}<2,74$ & $2,74<=\mathrm{x}=4$ & $0<=\mathrm{x}<2,00$ & $2,00<=\mathrm{x}<2,91$ & $2,91<=\mathrm{x}=4$ \\
\hline
\end{tabular}

Na rycinie 3 przedstawiono rozkład procentowy wypowiedzi uczniów na dany temat $\mathrm{w}$ grupach wyróżnionych ze względu na warunki rozwoju psychospołecznego $\mathrm{w}$ relacjach $\mathrm{z}$ rówieśnikami.

Uczniowie, dla których relacje z rówieśnikami są czynnikiem chroniącym w obu pomiarach, znacznie częściej niż pozostałe grupy badanych wyrażali zadowolenie z tego jaka klasa jest, nie chcieli żadnych w niej zmian. W I pomiarze odsetek takich odpowiedzi jest $\mathrm{w}$ tej grupie wyższy o 20,7 od badanych, dla których relacje z rówieśnikami są czynnikiem ryzyka i o 26,2 od grupy o przeciętnych wynikach w zakresie warunków rozwoju w relacjach $\mathrm{z}$ rówieśnikami. Pomimo że odsetek tego typu wypowiedzi w II pomiarze jest $\mathrm{w}$ grupie o najlepszych warunkach rozwoju w relacjach $\mathrm{z}$ rówieśnikami o 14 punktów procentowych niższy niż w I pomiarze, to i tak jest wyższy od wartości uzyskanej w grupie uczniów o wynikach typowych o 15,4 punktów procentowych i o 23,1 od wyniku w grupie ryzyka. W grupie dzieci, dla których relacje z rówieśnikami są czynnikiem ryzyka pomiędzy I a II pomiarem aż o 16,4\% dzieci mniej uznało, że nic nie trzeba zmieniać w klasie.

${ }^{28}$ Więcej na temat pierwszej wersji tej skali patrz: M. Deptuła, Poznawanie społecznego kontekstu rozwoju psychospołecznego uczniów w klasach IV-VI, Studia Edukacyjne 2015, 37, s. 61-76. 


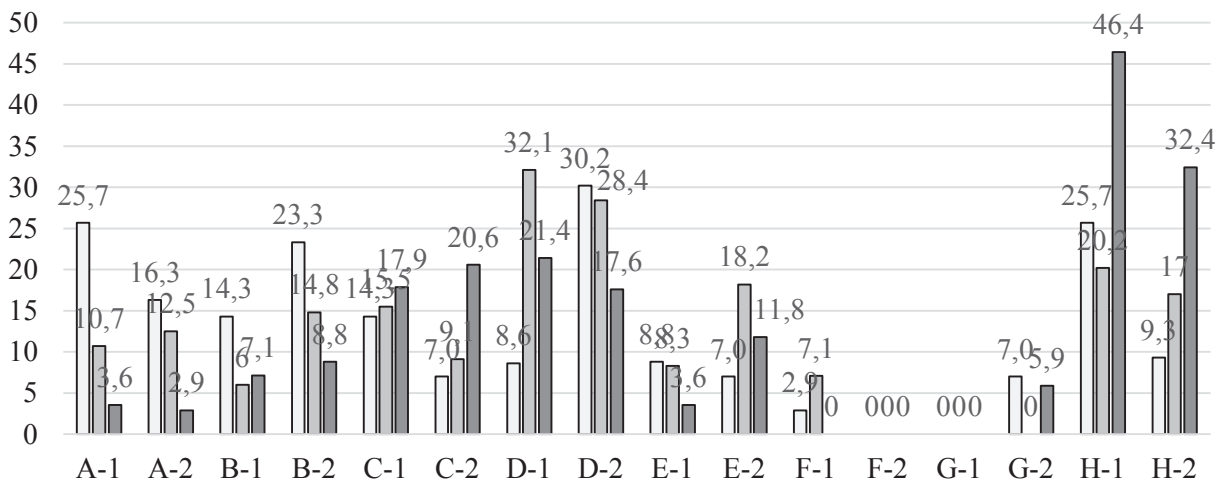

口Czynnik ryzyka w RR $\quad \square$ Wynik typowy w RR $\quad \square$ Czynnik chroniący w RR

Ryc. 3. Odsetek wypowiedzi uczniów na temat obszarów pożądanych zmian w klasie w grupach uczniów wyróżnionych ze względu na warunki rozwoju psychospołecznego $\mathrm{w}$ relacjach z rówieśnikami w klasie szkolnej w I i II pomiarze

Legenda:

- życzenia dotyczące zmian w odniesieniu do badanego dziecka: A - wzrostu pozytywnych zachowań (akceptacji, szacunku, wsparcia), B - zaprzestania agresji;

- życzenia dotyczące zmian w klasie: C - lepszych warunków do pracy na lekcjach (cisza, nieprzeszkadzanie), D - lepszej atmosfery i lepszych relacji między uczniami (większej więzi w klasie, wzajemnej pomocy, kultury osobistej), E - zaprzestania/zmniejszenia agresji, F - zwiększenia bezpieczeństwa fizycznego i psychicznego, G - żądanie wykluczenia danego ucznia z klasy;

- odpowiedzi wskazujące na zadowolenie z klasy takiej, jaką jest - H

Wynik testu Chi-kwadrat dla różnic pomiędzy wyżej wymienionymi grupami w zakresie częstotliwości wyrażania zadowolenia ze status quo i formułowania życzeń dotyczących zmian wskazuje, że zarówno w I pomiarze, jak i w II są one statystycznie istotne (odpowiednio 6,523, df $=2, p<0,05$ oraz $7,225 ; \mathrm{df}=2, \mathrm{p}<0,05)$.

Z porównania liczebności empirycznych i oczekiwanych w I pomiarze wynika, że w grupie uczniów, dla których relacje z rówieśnikami są czynnikiem chroniącym jest znacznie więcej wypowiedzi o tym, że w klasie nic nie trzeba zmieniać (różnica 5,6). Odwrotnie dzieje się w grupie o typowych wynikach w tym zakresie (różnica 5,3). Jedynie w grupie, dla której relacje z rówieśnikami są czynnikiem ryzyka, liczebności empiryczne są bardzo bliskie liczebnościom oczekiwanym (różnica 0,3). Tak więc można powiedzieć, że tylko uczniowie, którzy mają lepsze od pozostałych dwóch grup badanych warunki do rozwoju psychospołecznego $\mathrm{w}$ relacjach $\mathrm{z}$ rówieśnikami na początku klasy IV częściej akceptowali status quo. 
W II pomiarze prawidłowość zaobserwowana w grupie badanych, dla których relacje z rówieśnikami są czynnikiem chroniącym nadal się utrzymuje. Badani $\mathrm{z}$ tej grupy częściej niż to wynika z liczebności oczekiwanej deklarowali, że klasa nie wymaga zmian (różnica 4,8). W grupie uczniów o wynikach typowych liczebności empiryczne od oczekiwanych różnią się o 1; badani rzadziej wyrażali zadowolenie ze swojej klasy. Większe różnice (o 3,8) w tym zakresie odnotowano w grupie ryzyka; uczniowie $\mathrm{z}$ tej grupy rzadziej są zadowoleni z tego, jak ich traktują i jak się zachowują rówieśnicy w klasie.

Analiza częstości wypowiedzi dotyczących pożądanych zmian w klasie w I pomiarze pozwala dostrzec szczególne potrzeby uczniów z grupy ryzyka. Chcieliby oni większej akceptacji dla siebie i szacunku, lepszego kontaktu emocjonalnego i wsparcia (kategoria A) oraz zaprzestania wobec nich różnych form agresji (kategoria B). Takie potrzeby i problemy zdecydowanie rzadziej zgłaszali uczniowie, dla których relacje z rówieśnikami są czynnikiem chroniącym. W II pomiarze w grupie ryzyka odnotowano spadek (o 9,4\%) odsetka życzeń w kategorii A. Natomiast o 9 punktów wzrósł odsetek wypowiedzi w kategorii B. Pomiędzy I a II pomiarem odnotowano także w tej grupie wzrost o 21,6 punktów procentowych życzeń odnoszących się do poprawy atmosfery w klasie, pomagania sobie, życzliwości, więzi (kategoria D). Uczniowie, dla których relacje z rówieśnikami są czynnikiem chroniącym, zarówno w I jak i w II pomiarze bardzo rzadko zgłaszali potrzebę większej akceptacji dla siebie, szacunku czy wsparcia (różnica pomiędzy dziećmi z grupy ryzyka a nimi wynosi odpowiednio 22,1 i 13,4 punktu procentowego). Znacznie rzadziej skarżą się też na agresywne zachowania ze strony kolegów i koleżanek w klasie (różnica o 7,2 i 14,5pkt. na niekorzyść grupy ryzyka). Uczniowie o bardzo dobrych relacjach z rówieśnikami częściej niż pozostałe dwie grupy uczniów dopominali się natomiast o lepsze warunki do pracy na lekcjach - ciszę, nieprzeszkadzanie. Różnica ta jest widoczna zwłaszcza w II pomiarze w stosunku do uczniów z grup ryzyka wynosi 13,6, a do grupy o wyniku typowym o 11,6 punktów procentowych.

Różnice między grupami obserwowane w rozkładzie częstotliwości formułowania życzeń dotyczących wzrostu pozytywnych zachowań rówieśników wobec badanego (akceptacji, szacunku, wsparcia - kategoria A) oraz lepszych warunków do pracy na lekcjach i lepszej atmosfery w klasie (odpowiednio kategoria C i D) w porównaniu z częstotliwością skarg na agresywne zachowania rówieśników wobec badanego ucznia i występujące w klasie (kategorie B, E, F i G) w obu pomiarach są nieistotne statystycznie. 


\section{Stres odczuwany w związku ze szkołą i nauką a formułowane przez uczniów życzenia dotyczące zmian w klasie}

Do badania tej zmiennej wybrano pytanie: Wjakim stopniu odczuwasz stres zwiazany ze szkoła i nauką? stosowane w międzynarodowych badaniach nad zachowaniami zdrowotnymi młodzieży szkolnej Health Behaviour in School-aged Children - HBSC ${ }^{29}$. Badany miał do dyspozycji jedną z czterech odpowiedzi: wcale, trochę, dość mocno, bardzo mocno. Do grupy ryzyka ze względu na poziom stresu zaliczono uczniów, którzy wybrali odpowiedzi „dość mocno" lub „,bardzo mocno”. W kategorii czynników chroniących znaleźli się uczniowie deklarujący, że wcale nie odczuwają stresu, a w kategorii wyników typowych - uczniowie, którzy trochę odczuwają stres.

Na rycinie 4 przedstawiono częstotliwość zgłaszania przez badanych z tych trzech grup życzeń dotyczących zmian w klasie oraz deklaracji o braku takiej potrzeby.

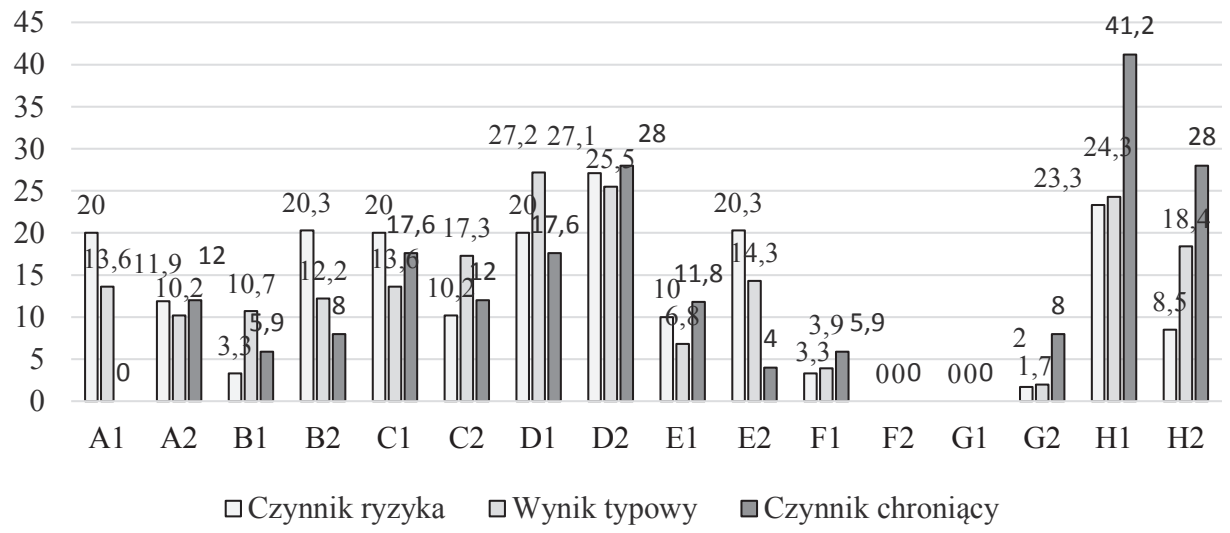

Ryc. 4. Odsetek wypowiedzi uczniów na temat obszarów pożądanych zmian w klasie w grupach uczniów wyróżnionych ze względu na stres odczuwany w związku ze szkołą i nauką w I i II pomiarze

Legenda:

- życzenia dotyczące zmian w odniesieniu do badanego dziecka: A - wzrostu pozytywnych zachowań (akceptacji, szacunku, wsparcia), B - zaprzestania agresji;

- życzenia dotyczące zmian w klasie: C - lepszych warunków do pracy na lekcjach (cisza, nieprzeszkadzanie), D - lepszej atmosfery i lepszych relacji między uczniami (większej więzi w klasie, wzajemnej pomocy, kultury osobistej), E - zaprzestania/zmniejszenia agresji, F - zwiększenia bezpieczeństwa fizycznego i psychicznego, G - żądanie wykluczenia danego ucznia z klasy;

- odpowiedzi wskazujące na zadowolenie z klasy takiej, jaką jest - H

${ }^{29}$ J. Mazur (red.), Zdrowie i zachowania zdrowotne młodzieży szkolnej w Polsce na tle wybranych uwarunkowań socjodemograficznych. Wyniki badań HBSC 2014, Warszawa 2015. 
W I pomiarze uczniowie deklarujący, że nie odczuwają w ogóle stresu związanego ze szkołą i nauką najczęściej, w porównaniu z dwiema pozostałymi grupami, wyrażali zadowolenie ze swojej klasy. Różnica między nimi a uczniami z grupy ryzyka wynosi 17,9 punktów procentowych. Wynik w grupie "trochę" doświadczającej stresu jest tylko o 1 punkt niższy. Chociaż w II pomiarze we wszystkich grupach poziom zadowolenia był znacznie niższy, to różnice między nimi odnotowane w I pomiarze nadal występują. Wśród uczniów z grupy ryzyka deklaracje, że nic w klasie nie trzeba zmieniać złożyło o 19,5\% mniej badanych niż w grupie, dla której poziom stresu uznano za czynnik chroniący i o prawie 10\% mniej, niż w grupie odczuwającej stres tylko trochę. Obserwowane różnice są jednak w obu pomiarach statystycznie nieistotne ( $\mathrm{w}$ II pomiarze wartość Chi-kwadrat $=5,40$, dla df $=2$, $\mathrm{p}=0,067$; wartość krytyczna na poziomie $\mathrm{p}<0,005$ wynosi 5,991).

Uczniowie z grupy ryzyka w I pomiarze częściej od pozostałych dwóch grup pragnęli doświadczać akceptacji, szacunku i wsparcia, a różnica między nimi i uczniami nie odczuwającymi wcale stresu w związku ze szkołą i nauką, gdzie nie odnotowano żadnej wypowiedzi tego typu, wynosiła 20 punktów procentowych. W II pomiarze uczniowie z grupy ryzyka częściej niż obie pozostałe grupy skarżą się na różne formy agresji ze strony koleżanek i kolegów z klasy. Dzieciom z tej grupy także najbardziej przeszkadzają agresywne zachowania $\mathrm{w}$ klasie. Różnica między nimi a uczniami nie odczuwającymi stresu wynosi w pierwszym przypadku 12,3 punktu procentowego, $\mathrm{w}$ drugim 16,3. Powstaje pytanie: kto jest sprawcą agresji wobec tych uczniów.

Analiza częstotliwości formułowania życzeń dotyczących wzrostu pozytywnych zachowań wobec badanego i w klasie (kategorie A, C, D) oraz życzeń dotyczących zaprzestania agresji i zachowań zagrażających poczuciu bezpieczeństwa (kategorie B, E, F, G), obserwowane w grupach porównywanych ze względu na poziom stresu odczuwanego w związku ze szkołą i nauką, są w I i II pomiarze nieistotne statystycznie.

\section{Stosunek emocjonalny do szkoły a formułowane przez uczniów życzenia dotyczące zmian w klasie}

Stosunek emocjonalny do szkoły badano za pomocą pytania stosowanego w badaniach HBSC: Co sądzisz obecnie o swojej szkole? Uczniowie wybierali jedną z następujących opcji: „nie lubię jej wcale”, , "niezbyt ją lubię”, , trochę ją lubię", ",bardzo ją lubię"30. Uczniowie, którzy wybrali odpowiedź „nie lubię

${ }^{30}$ Tamże. 
jej wcale” lub „niezbyt ją lubię” zostali zaliczeni do grupy ryzyka. Badanych, którzy wybrali opcję "trochę ją lubię" przypisano do grupy, której stosunek do szkoły określono jako wynik typowy. Odpowiedź „bardzo ją lubię" uznano za czynnik chroniący.

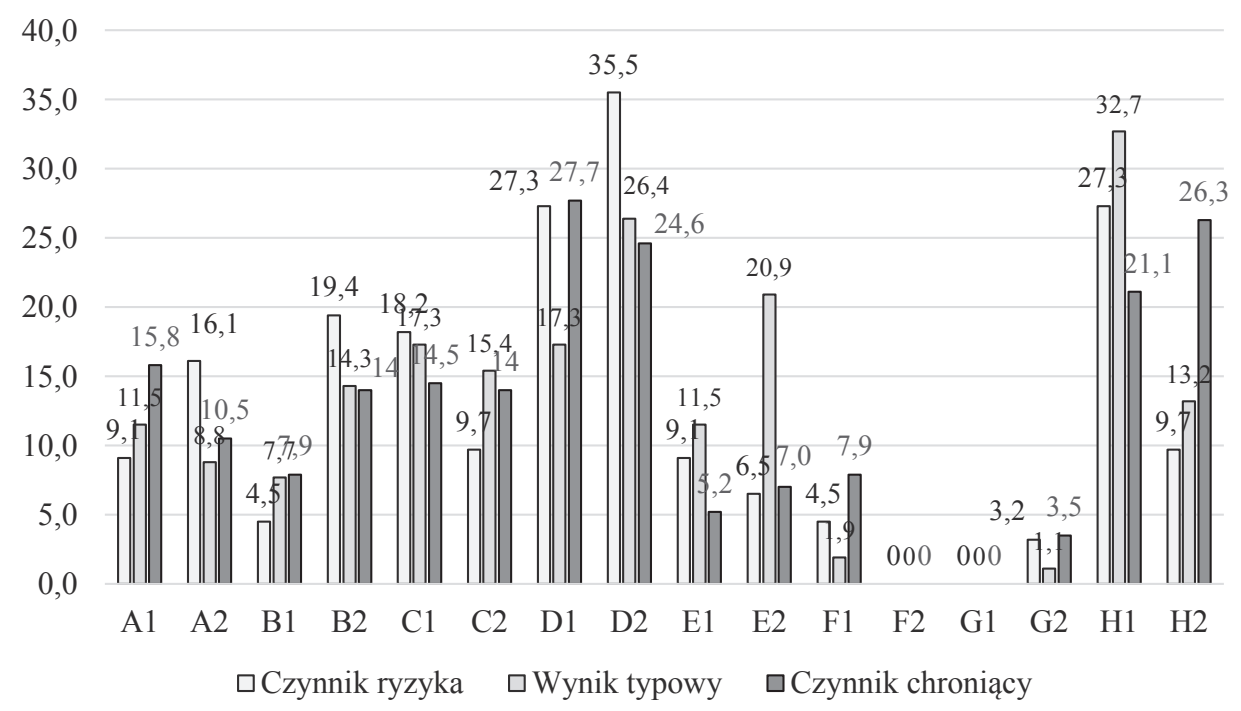

Ryc. 5. Odsetek wypowiedzi uczniów na temat obszarów pożądanych zmian w klasie w grupach uczniów wyróżnionych ze względu na stosunek emocjonalny do szkoły w I i II pomiarze

Legenda:

- życzenia dotyczące zmian w odniesieniu do badanego dziecka: A - wzrostu pozytywnych zachowań (akceptacji, szacunku, wsparcia), B - zaprzestania agresji;

- życzenia dotyczące zmian w klasie: C - lepszych warunków do pracy na lekcjach (cisza, nieprzeszkadzanie), D - lepszej atmosfery i lepszych relacji między uczniami (większej więzi w klasie, wzajemnej pomocy, kultury osobistej), E - zaprzestania/zmniejszenia agresji, F - zwiększenia bezpieczeństwa fizycznego i psychicznego, G - żądanie wykluczenia danego ucznia z klasy; - odpowiedzi wskazujące na zadowolenie z klasy takiej, jaką jest - H

W I pomiarze uczniowie zaliczeni do grupy ryzyka ze względu na to, że nie lubią szkoły lub niezbyt ją lubią, częściej niż uczniowie, którzy bardzo ją lubią, deklarowali, że niczego w klasie nie trzeba zmieniać (różnica o 7,2 punktu procentowego). Najwięcej zadowolonych ze swojej klasy było w grupie uczniów, którzy trochę lubią swoją szkołę. Jednak już w II pomiarze zachodzi odwrotna zależność. W grupie ryzyka odsetek dzieci deklarujących, że klasa nie wymaga zmian jest o 16,6 pkt. niższy niż w grupie, której stosunek do szkoły jest czynnikiem chroniącym i o 3,5 pkt. niższy, niż w grupie uczniów, których stosunek do szkoły można określić jako przeciętny. Różnice obserwowane między tymi grupami są statystycznie nieistotne w I i II pomia- 
rze ( $w$ II pomiarze Chi-kwadrat $=5,672, \mathrm{df}=2, \mathrm{p}<0,058$; wartość krytyczna Chi-kwadrat $=5,991$ dla $\mathrm{p}=0,05$ ).

O ile w grupie dzieci deklarujących w pomiarze II, że bardzo lubią swoją szkołę odnotowano wzrost (o 5,2 pkt.) uczniów zadowolonych ze swojej klasy, o tyle wśród dzieci z grupy ryzyka i w grupie o przeciętnie pozytywnym stosunku do swojej klasy odnotowano mniej uczniów zadowolonych ze swojej klasy (odpowiednio o 17,6 i 19, 5 pkt.).

Porównanie dzieci z grupy ryzyka z dziećmi, których stosunek do szkoły jest czynnikiem chroniącym, w zakresie życzeń dotyczących pożądanych zmian w klasie w I pomiarze prowadzi do wniosku, że uczniowie, którzy bardzo lubią swoją szkołę częściej zgłaszali potrzebę większej akceptacji, szacunku i wsparcia (kategoria A), niż badani z pozostałych dwóch grup. Natomiast $\mathrm{w}$ II pomiarze uczniowie z grupy ryzyka nieco częściej skarżyli się na agresywne zachowania wobec nich i wyrażali pragnienie większej akceptacji, szacunku i wsparcia.

Analiza różnic między grupą uczniów, którzy nie lubią swojej szkoły (grupa ryzyka), grupą uczniów, którzy trochę ją lubią (wyniki typowe) i grupą uczniów, którzy mają do niej pozytywny stosunek (czynnik chroniący) w zakresie formułowania życzeń dotyczących wzrostu pozytywnych zachowań wobec badanego i w klasie (kategorie A, C, D) oraz życzeń dotyczących zaprzestania agresji i zachowań zagrażających poczuciu bezpieczeństwa (kategorie B, E, F, G) wskazuje, że są one w obu pomiarach nieistotne statystycznie.

\section{Podsumowanie}

Zebrane $\mathrm{w}$ toku badań podłużnych wypowiedzi uczniów w wieku 10-11 lat wskazują na istotne problemy, z jakimi stykają się oni w szkole. Zarówno w I jak i II pomiarze wypowiedzi pochodzą od nieco ponad połowy uczniów, którzy wypełnili ankietę dotyczącą relacji z rówieśnikami. Część wypowiedzi dotyczyła własnych doświadczeń dzieci związanych z brakiem poczucia akceptacji, szacunku, wsparcia oraz doświadczaniem przemocy. Część odnosiła się do braku zadowolenia z klimatu społecznego klasy. Wśród wypowiedzi uczniów znalazły się też i takie, które wyrażały zadowolenie z tego, jaka jest klasa. Stanowiły one blisko $1 / 3$ wszystkich wypowiedzi w I pomiarze i blisko 1/5 w II. Zakres tematyczny wypowiedzi uczniów klas IV, którzy uczestniczyli w prezentowanym badaniu jest zgodny z tym, jaki został opisany we wcześniejszych badaniach wśród uczniów klas IV-VI' ${ }^{31}$. Zbieżność ta może wskazywać, że problemy związane z za-

\footnotetext{
${ }^{31}$ M. Deptuła, Co uczniowie klas IV, Vi VI chcieliby zmienić w swojej klasie? s. 127-150.
} 
grożonym poczuciem bezpieczeństwa, zwłaszcza psychicznego, występują wśród uczniów bez względu na ich wiek. Wskazuje to na niekorzystny klimat społeczny klasy.

Przedmiotem dalszych analiz były różnice $\mathrm{w}$ treści poruszanych wątków ze względu na płeć, wiek, warunki rozwoju psychospołecznego w relacjach $\mathrm{z}$ rówieśnikami, stres odczuwany w związku z nauką i szkołą, stosunek emocjonalny do szkoły. Ustalono, że na początku roku szkolnego chłopcy częściej niż dziewczynki wyrażali zadowolenie z tego, jaka jest ich klasa, a różnice między nimi były istotne statystycznie. Pod koniec roku wypowiedzi tego typu było już mniej w obu grupach, a różnice między nimi nieistotne statystycznie. Natomiast wiek osób badanych w żadnym z pomiarów nie różnicował częstotliwości zgłaszanych przez nich życzeń zarówno wobec klasy, jak i wobec badanego ucznia. Stwierdzono również brak istotnych różnic między wypowiedziami uczniów w grupach wyróżnionych ze względu na ryzyko vs ochronę ze względu na zmienne odnoszące się do środowiska szkolnego, takie jak poziom odczuwanego stresu związanego z nauką i szkołą oraz stosunek emocjonalny do szkoły.

Natomiast, odnotowano istotne statystycznie różnice w treściach wypowiedzi uczniów w zależności od warunków do rozwoju psychospołecznego, jakie mają oni $w$ relacjach z rówieśnikami. Uczniowie, dla których relacje z rówieśnikami są czynnikiem chroniącym częściej deklarowali zadowolenie ze swojej klasy $\mathrm{w}$ obu pomiarach, niż uczniowie z grupy ryzyka i z grupy o przeciętnych warunkach rozwoju psychospołecznego w relacjach rówieśniczych w swojej klasie. Ze względu na to, że skala do badania tych warunków rozwoju jest narzędziem o wysokich parametrach psychometrycznych ${ }^{32}$, można powiedzieć, że wychowawca klasy może uzyskać rzetelną wiedzę na temat tego, co dzieje się $\mathrm{w}$ relacjach między dziećmi zapewniając im anonimowość i zadając właśnie takie pytanie: co chciałyby zmienić w swojej klasie. Może być ono punktem wyjścia do wspólnego zastanawiania się, jak to osiągnąć i dobierania sposobów działania. $W$ ten sposób program pracy wychowawczej może powstać wspólnie z dziećmi, a po zaakceptowaniu go przez rodziców być realizowany. Wybór tej drogi zwiększa szanse na wewnętrzną motywację uczniów do realizacji tak stworzonego programu oraz rozwój poczucia sprawstwa, co stanowi wstęp do rozwijania kapitału społecznego, któ-

${ }^{32}$ Rzetelność $\mathrm{w}$ prezentowanych tu badaniach w całej próbie uczniów klas IV ( $\left.\mathrm{N}=305\right)$ w I i II pomiarze Alfa Cronbacha wyniosła odpowiednio 0,90 i 0,92, a średnia korelacja między pozycjami skali - 0,30 i 0,37. W badaniach przekrojowych uczniów klas IV, V i VI cytowanych już w tym artykule $(\mathrm{N}=910)$ Alfa Cronbacha - 0,93, a średnia korelacja między pozycjami - 0,40. Natomiast, w wybranej z całej tej próby mniejszej grupy, w której powtórzono pomiar po 4-6 tygodniach Alfa Cronbacha - 0,95 i 0,92, a średnia korelacja między pozycjami - 0,50 i 0,39. Stałość uzyskanych wyników mierzona współczynnikiem $r$ Pearsona wyniosła 0,76, p <0,05. Więcej na ten temat $\mathrm{w}$ przygotowywanej przez Deptułę publikacji dotyczącej tej skali. 
rego tak nam w Polsce brakuje. Szkoła jest najważniejszym miejscem społecznych interakcji, które są podstawą tworzenia warunków do uczenia dzieci demokracji w praktyce. Podobnie można pewnie wykorzystać odpowiedzi na otwarte pytanie dotyczące pożądanych przez dzieci zmian w pracy nauczycieli, o czym napiszemy wkrótce. Ważne jest jednak, by wychowawca klasy potrafił przełożyć zgłoszone przez dzieci potrzeby i problemy na działania wspierające rozwój ich umiejętności życiowych.

Wyniki tych badań wskazują też inne możliwe kierunki szkolnych działań profilaktycznych, których celem powinno być włączanie uczniów $\mathrm{w}$ zapobieganie/ograniczanie agresji i przemocy między nimi. Internet i sprzęt elektroniczny, którym obecnie dzieci dysponują sprawia, że szanse dorosłych na dostrzeżenie agresji i przemocy dokonywanej tą drogą są niewielkie, a dramaty nękanych dzieci pozbawionych wsparcia dorosłych i rówieśników olbrzymie. $Z$ tego powodu praca nad poprawą klimatu społecznego w klasie musi być wspólną sprawą uczniów, wychowawcy klasy i rodziców.

Jak widać z częstotliwości wypowiedzi na temat potrzeby ciszy, nie przeszkadzania na lekcji, nauczyciele mogą mieć sporą grupę sojuszników w jej utrzymywaniu, jeśli wspólnie z dziećmi znajdą sposób na rozwiązywanie problemów, które prowadzą do zakłócania pracy na lekcji. Nie bez znaczenia będzie tu z pewnością zmiana sposobu pracy tak, by każdy uczeń mógł realizować zadania ważne dla siebie i dostosowane do jego możliwości, jeśli się zaangażuje.

Ważne jest również, aby nauczyciele pamiętali, że modelują sposób komunikowania się między dziećmi i nauczyli się konstruktywnie radzić sobie z napięciem oraz frustracją, jakie nieuchronnie towarzyszą ich trudnej pracy w systemie, który w naszej opinii nikomu już dobrze nie służy, ani dzieciom, ani nauczycielom, ani naszemu społeczeństwu i jego przyszłości.

\section{BIBLIOGRAFIA}

Anderson C., The Search for school climate, Review of Educational Research, 1997, 52(3).

Bańka A., Społeczna psychologia środowiskowa, Wydawnictwo Naukowe Scholar, Warszawa 2002.

Borsich Sz., Deptuła M., Propozycja narzędzia do pomiaru natężenia poczucia zagrożenia stereotypem wśród dzieci, opracowanego na podstawie koncepcji multizagrożeń Jenessy Shapiro i Stevena Neuberga, Studia Edukacyjne, 2018, 49.

Brzezińska A.I., Jak przebiega rozwój człowieka? [w:] Psychologiczne portrety człowieka. Praktyczna psychologia rozwojowa, red. A.I. Brzezińska, Gdańskie Wydawnictwo Psychologiczne, Gdańsk 2005.

Brzeziński J., Metodologia badań psychologicznych, Wydawnictwo Naukowe PWN, Warszawa 1996. 
Cohen J., Geier V.K., School Climate Research Summary, New York 2010 January (www. schoolclimate.org/climate/research.php) [dostęp: 11.04.2019].

Deptuła M., Odrzucenie rówieśnicze. Profilaktyka i terapia, Wydawnictwo Naukowe PWN, Warszawa 2013.

Deptuła M., Poznawanie społecznego kontekstu rozwoju psychospołecznego w klasach IV-VI, Studia Edukacyjne, 2015, 37.

Deptuła M., Co uczniowie klas IV, Vi VI chcieliby zmienić w swojej klasie? Swobodne wypowiedzi uczniów jako podstawa do wnioskowania o warunkach rozwoju psychospołecznego uczniów w relacjach z rówieśnikami, Przegląd Pedagogiczny, 2016, 2.

Deptuła M., Borsich Sz., "Niebieskoocy” w naszej szkole - przezwyciężanie stereotypów droga do tworzenia uczniom lepszych warunków rozwoju w klasie szkolnej, Studia Edukacyjne, 2017, 46.

Deptuła M., Potorska A., Borsich Sz., Wczesna profilaktyka w rozwoju psychospołecznym i zachowan ryzykownych, Wydawnictwo Naukowe PWN, Warszawa 2018.

Erikson E.H., Dzieciństwo i społeczeństwo, Dom Wydawniczy Rebis, Poznań 1997.

Fromm E., O sztuce miłości, Dom Wydawniczy Rebis, Poznań 2005.

Garmezy N., Stres-Resistant Children: The Search for Protective Factors, [w:] Recent Research in Developmnetal Psychopatology, red. J. Stevenson, Pergamon Press, Oxford - New York Toronto - Sydney - Paris - Frankfurt 1985.

Junik W., Ewaluacja zasobów szkoły i diagnoza występujacych w niej zagrożęn, [w:] Profilaktyka w grupach ryzyka. Część I - Diagnoza, Wydawnictwo Edukacyjne Parpamedia, Warszawa 2009.

Kołakowski A., Budowanie ustrukturyzowanego i przyjaznego środowiska w klasie, [w:] Zaburzenia psychiczne i rozwojowe u dzieci a szkolna rzeczywistość, red. M Jerzak, Wydawnictwo Naukowe PWN, Warszawa 2016.

Krejtz K., Krejtz I., Metoda analizy treści - teoria i praktyka badawcza, [w:] Wywiad psychologiczny. Wywiad jako postępowanie badawcze, red. K. Stemplewska-Żakowicz, K. Krejtz, Pracownia Testów Psychologicznych Polskiego Towarzystwa Psychologicznego, Warszawa 2005.

Kulesza M., Klimat szkoły a zachowania przemocowe uczniów w świetle wybranych badań empirycznych, www.seminare.pl/24/Kulesza 2007.pdf [dostęp: 12.11.2018].

Kwiatkowski P., Mądrość - zasoby - pozytywna adaptacja, [w:] Teorie i konteksty profilaktyki niedostosowania społecznego, red. P. Kwiatkowski, Oficyna Wydawnicza ATUT, Wrocław 2016.

Luthar S.S., Resilience in development. A synthesis of research across five decades, [w:] Developmental Psychopatology. Risk, disorder, and adaptation, Volume 3 (2 edition), red. D. Cicchetti, D.J. Cohen, Wiley, New York 2006.

Maslow A., Motywacja i osobowość, Instytut Wydawniczy PAX, Warszawa 1990.

Masten A.S., Powell J.L., Resilience Framework for Research Policy and Practice, [w:] Resilience and Vulnerability, red. S.S .Luthar, Cambridge University Press, Cambridge 2003.

Mazur J. (red.), Zdrowie i zachowania zdrowotne młodzieży szkolnej w Polsce na tle wybranych uwarunkowań socjodemograficznych. Wyniki badań HBSC 2014, Instytut Matki i Dziecka, Warszawa 2015.

Obuchowski K., Psychologia dążeń ludzkich, Wydawnictwo Naukowe PWN, Warszawa 1983.

Oleś M., Jakość życia u dzieci i młodzieży - przegląd metod pomiaru, Przegląd Psychologiczny, 2010, 53, 2, http://www.kul.pl/files/714/nowy_folder/2.53.2010_art.6.pdf [dostęp: 17.05.2019]. 
Oleś M., Kryteria jakości życia młodzieży, Rocznik Filozoficzny Ignatianum, https:/ /czasopisma.ignatianum.edu.pl/index.php/rfi XXII / 1, [dostęp: 17.05.2019].

Ostaszewski K., Czynniki ryzyka i czynniki chroniace w zachowaniach ryzykownych dzieci i mtodzieży, [w:] Czynniki chroniace młodzież 15-letnia przed podejmowaniem zachowań ryzykownych, red. J. Mazur, I. Tabak, A. Małkowska-Szkutnik, K. Ostaszewski, H. Kołoło, A. Dzielska, A. Kowalska, Instytut Matki i Dziecka. Zakład Ochrony i Promocji Zdrowia Dzieci i Młodzieży, Warszawa 2008.

Ostaszewski K., Zachowania ryzykowne młodzieży w perspektywie mechanizmów resilience, Instytut Psychioatrii i Neurologii, Warszawa, 2014.

Rogers C., Sposób bycia, przekł. M. Karpiński, Dom Wydawniczy Rebis, Poznań 2002.

Schaffer H.R., Psychologia rozwojowa. Podstawowe pojęcia, Wydawnictwo Uniwersytetu Jagiellońskiego, Kraków 2006.

Schaffer H.R., Rozwój społeczny. Dzieciństwo i młodość, Kraków Wydawnictwo Uniwersytetu Jagiellońskiego 2006.

Smykowski B., Psychologia kryzysów kulturowych rozwoju dzieci i młodzieży, Wydawnictwo Naukowe UAM, Poznań 2012.

Zimmerman M.A., Arunkumar R., Resiliency research: Implications for schools and policy, Social Policy Report, Society for Research in Child Development, 1994, 9(4). 